\title{
Contributions of trans-boundary transport to summertime air quality in Beijing, China
}

\author{
Jiarui Wu ${ }^{1,3}$, Guohui $\mathrm{Li}^{1}$, Junji Cao ${ }^{1}$, Naifang $\mathrm{Bei}^{2}$, Yichen Wang ${ }^{1}$, Tian Feng ${ }^{1,2}$, Rujin Huang ${ }^{1}$, Suixin Liu ${ }^{1}$, \\ Qiang Zhang ${ }^{4}$, and Xuexi Tie ${ }^{1}$ \\ ${ }^{1}$ Key Lab of Aerosol Chemistry and Physics, SKLLQG, Institute of Earth Environment, Chinese Academy of Sciences, \\ Xi'an, China \\ ${ }^{2}$ School of Human Settlements and Civil Engineering, Xi'an Jiaotong University, Xi' an, Shaanxi, China \\ ${ }^{3}$ University of Chinese Academy of Science, Beijing, China \\ ${ }^{4}$ Department of Environmental Sciences and Engineering, Tsinghua University, Beijing, China \\ Correspondence to: Guohui Li (ligh@ieecas.cn) and Junji Cao (jjcao@ieecas.cn)
}

Received: 4 August 2016 - Discussion started: 10 August 2016

Revised: 14 January 2017 - Accepted: 16 January 2017 - Published: 10 February 2017

\begin{abstract}
In the present study, the WRF-CHEM model is used to evaluate the contributions of trans-boundary transport to the air quality in Beijing during a persistent air pollution episode from 5 to 14 July 2015 in Beijing-Tianjin-Hebei (BTH), China. Generally, the predicted temporal variations and spatial distributions of $\mathrm{PM}_{2.5}$ (fine particulate matter), $\mathrm{O}_{3}$ (ozone), and $\mathrm{NO}_{2}$ are in good agreement with observations in BTH. The WRF-CHEM model also reproduces reasonably well the temporal variations of aerosol species compared to measurements in Beijing. The factor separation approach is employed to evaluate the contributions of transboundary transport of non-Beijing emissions to the $\mathrm{PM}_{2.5}$ and $\mathrm{O}_{3}$ levels in Beijing. On average, in the afternoon during the simulation episode, the local emissions contribute $22.4 \%$ to the $\mathrm{O}_{3}$ level in Beijing, less than $36.6 \%$ from non-Beijing emissions. The $\mathrm{O}_{3}$ concentrations in Beijing are decreased by $5.1 \%$ in the afternoon due to interactions between local and non-Beijing emissions. The non-Beijing emissions play a dominant role in the $\mathrm{PM}_{2.5}$ level in Beijing, with a contribution of $61.5 \%$, much higher than $13.7 \%$, from Beijing local emissions. The emission interactions between local and nonBeijing emissions enhance the $\mathrm{PM}_{2.5}$ concentrations in Beijing, with a contribution of $5.9 \%$. Therefore, the air quality in Beijing is generally determined by the trans-boundary transport of non-Beijing emissions during summertime, showing that the cooperation with neighboring provinces to mitigate pollutant emissions is key for Beijing to improve air quality.
\end{abstract}

\section{Introduction}

Beijing, the capital of China, has become an environmentally stressed city due to a growing population, increasing transportation activity, and city expansion (Parrish and Zhu, 2009). Beijing is situated in northeastern China, surrounded from the southwest to the northeast by the Taihang Mountains and the Yanshan Mountains and open to the North China Plain (NCP) in the south and east. Unfortunately, the NCP has become one of the most polluted areas in China due to rapid industrialization and urbanization (Zhang et al., 2013). When south or east winds are prevalent in the NCP, air pollutants originating in the NCP are transported to Beijing and surrounding areas and subject to accumulation due to the mountain blocking, causing heavy air pollution in Beijing (Long et al., 2016).

$\mathrm{PM}_{2.5}$ (fine particulate matter) and $\mathrm{O}_{3}$ (ozone) are considered to be the most serious air pollutants of concern in Beijing during summertime (e.g., Xie et al., 2015; Zheng et al., 2015; Chen et al., 2015; Wang et al., 2016). The mean summertime $\mathrm{PM}_{2.5}$ mass concentration was about $80 \mu \mathrm{g} \mathrm{m}^{-3}$ in 2013 (R. K. Li et al., 2015), exceeding the second grade of National Ambient Air Quality Standards (NAAQS) in China and also exceeding the average $\mathrm{PM}_{2.5}$ concentration of $78.1 \mu \mathrm{g} \mathrm{m}^{-3}$ during the period from 2004 to 2012 (Liu et al., 2015). During haze pollution events in summer 2014, the $\mathrm{PM}_{2.5}$ concentration generally reaches $100 \mu \mathrm{g} \mathrm{m}^{-3}$, and even exceeds $150 \mu \mathrm{g} \mathrm{m}^{-3}$ in Beijing (Wang et al., 2016). An in- 
creasing $\mathrm{O}_{3}$ trend has been observed in Beijing from 2002 to 2010 (Wang et al., 2012; Y. H. Wang, 2013). The average maximum $1 \mathrm{~h} \mathrm{O}$ concentration has been reported to achieve $140 \mu \mathrm{g} \mathrm{m}^{-3}$ during summertime of 2013 in Beijing (L. T. Wang et al., 2014). Wang et al. (2016) have demonstrated that the summertime $\mathrm{O}_{3}$ mass concentration reached high levels in 2014 in Beijing, with a daily average of up to $110 \mu \mathrm{g} \mathrm{m}^{-3}$. Chen et al. (2015) have further shown that the average maximum daily $\mathrm{O}_{3}$ concentrations were higher than $150 \mu \mathrm{g} \mathrm{m}^{-3}$ during the summer in 2015 at most of the monitoring sites in Beijing.

In recent years, Beijing has implemented aggressive emission control strategies to ameliorate the air quality (Parrish and Zhu, 2009). Both $\mathrm{NO}_{x}\left(\mathrm{NO}+\mathrm{NO}_{2}\right)$ and total VOCs (volatile organic compounds) in Beijing have decreased linearly since 2002, while the daytime average $\mathrm{O}_{3}$ concentration still increased rapidly (Tang et al., 2009; Wang et al., 2012; Zhang et al., 2014). Zhang et al. (2014) have highlighted the importance of the trans-boundary transport and the cooperation with neighboring provinces to control the $\mathrm{O}_{3}$ level in Beijing. Pollutants transported from outside of Beijing and formed locally together determine the air quality in Beijing (Meng et al., 2006; Zhang et al., 2012).

Several studies have been performed to investigate the role of trans-boundary transport in the air quality of Beijing based on observational analyses and model simulations. Using the US EPA (Environmental Protection Agency) Model3/CMAQ (Community Multiscale Air Quality) model simulation in the Beijing area, Streets et al. (2007) have pointed out that Hebei Province can contribute 50-70\% of Beijing's $\mathrm{PM}_{2.5}$ concentration and $20-30 \%$ of $\mathrm{O}_{3}$ concentration. Wang et al. (2009) have indicated that $\mathrm{O}_{3}$ formation in Beijing is not only affected by local emissions, but also influenced by Tianjin and the south of Hebei Province. The intense regional transport of pollutants from south to north in the NCP has been proposed to be the main reason for the heavy haze pollution in January 2013 in Beijing (Sun et al., 2014; Tao et al., 2014; Z. Wang et al., 2014). Jiang et al. (2015) have demonstrated that the transport from the environs of Beijing contributed about $55 \%$ of the peak $\mathrm{PM}_{2.5}$ concentration in the city during a heavy haze event in December 2013.

Since September 2013, the "Atmospheric Pollution Prevention and Control Action Plan" (hereafter referred to as APPCAP) has been implemented, which was released by the Chinese State Council to reduce $\mathrm{PM}_{2.5}$ by up to $25 \%$ by 2017 relative to 2012 levels. After implementation of the APPCAP, high $\mathrm{PM}_{2.5}$ mass concentrations still can be observed and the $\mathrm{O}_{3}$ pollution has deteriorated during summertime since 2013 in Beijing (Chen et al., 2015; Wang et al., 2016). Hence, to support the design of mitigation strategies, studies are imperative to explore the $\mathrm{O}_{3}$ and $\mathrm{PM}_{2.5}$ formation from various sources and evaluate the pollutants' contributions from local production and trans-boundary transport in Beijing.

The purpose of the present study is to evaluate the contributions of trans-boundary transport of emissions outside of Beijing to the air quality in Beijing and interaction of emissions in and outside of Beijing after APPCAP using the WRF-CHEM model. The model configuration and methodology are described in Sect. 2. Model results and sensitivity studies are presented in Sect. 3, and conclusions and discussions are given in Sect. 4.

\section{Model and methodology}

\subsection{WRF-CHEM model}

The WRF-CHEM model used in the study is developed by Li et al. (2010, 2011a, b, 2012) at the Molina Center for Energy and the Environment, with a new flexible gas-phase chemical module and the CMAQ aerosol module developed by the US EPA. The aerosol component of the CMAQ model is designed to be an efficient and economical depiction of aerosol dynamics in the atmosphere (Binkowski and Roselle, 2003). The particle size distribution in the study is represented as the superposition of three lognormal subdistributions, called modes, which includes the processes of coagulation, particle growth by the addition of mass, and new particle formation. Following the work of Kulmala et al. (1998), the new particle production rate presented here is calculated as a parameterized function of temperature, relative humidity, and the vapor-phase $\mathrm{H}_{2} \mathrm{SO}_{4}$ concentration due to binary nucleation of $\mathrm{H}_{2} \mathrm{SO}_{4}$ and $\mathrm{H}_{2} \mathrm{O}$ vapor, and the new particles are assumed to be $2.0 \mathrm{~nm}$ diameter. A number of recent studies have shown that organic compounds can play an important role in the nucleation process (Zhang et al., 2009, 2012; R. Y. Zhang, 2015). The contribution from organic acids likely explains the high levels of aerosol, especially in polluted urban areas, where large amount of organic acids can be emitted directly and produced by photochemical oxidation of hydrocarbons (Fan et al., 2006), which needs to be considered in further studies. The wet deposition follows the method used in the CMAQ and the surface deposition of chemical species is parameterized following Wesely (1989). The photolysis rates are calculated using the FTUV (fast radiation transfer model) (Li et al., 2005, 2011a), in which the effects of aerosols and clouds on photolysis are considered.

The inorganic aerosols are predicted in the WRF-CHEM model using ISORROPIA Version 1.7 (Nenes et al., 1998). The efficient and rapid secondary species formation in Beijing has been found during the severe haze formation process in the previous study (Guo et al., 2014). The secondary organic aerosol (SOA) formation is calculated using a nontraditional SOA module. The volatility basis set (VBS) modeling method is used in the module, assuming that primary organic components are semi-volatile and photochemically reactive and are distributed in logarithmically spaced volatility bins. Detailed information about the VBS approach can be found in Li et al. (2011b). Recent studies have shown that small di-carbonyls (glyoxal and methylglyoxal) are impor- 
tant for the aerosol formation due to their traffic origin (Zhao et al., 2006; Gomez et al., 2015). Li et al. (2011a) have indicated that glyoxal and methylglyoxal can contribute about $10 \%$ of the SOA in the urban area of Mexico City. The SOA formation from glyoxal and methylglyoxal in this study is parameterized as a first-order irreversible uptake by aerosol particles and cloud droplets, with a reactive uptake coefficient of $3.7 \times 10^{-3}$ for glyoxal and methylglyoxal (Zhao et al., 2006; Volkamer et al., 2007; Gomez et al., 2015).

\subsection{Pollution episode simulation}

A persistent air pollution episode from 5 to 14 July 2015 in Beijing-Tianjin-Hebei (BTH) is simulated using the WRFCHEM model. During the episode, the observed mean daily $\mathrm{PM}_{2.5}$ concentration is $73.8 \mu \mathrm{g} \mathrm{m}^{-3}$ and the average $\mathrm{O}_{3}$ concentration in the afternoon reaches $237.0 \mu \mathrm{g} \mathrm{m}^{-3}$ in Beijing. The maximum of $\mathrm{O}_{3}$ concentration is higher than $350 \mu \mathrm{g} \mathrm{m}^{-3}$, and the maximum of $\mathrm{PM}_{2.5}$ concentration can reach a high level exceeding $150 \mu \mathrm{g} \mathrm{m}^{-3}$. Supplement Fig. S1a-c show the daily averages of the temperature, relative humidity, and wind speed in Beijing during the summer of 2015 . The minimum air temperature is $18.7^{\circ}$, and the maximum air temperature is $40^{\circ}$ during the summer, with an average of $25.7^{\circ}$. The average relative humidity is $63.8 \%$. The southeast or southwest wind is prevailing over the NCP due to the influence of East Asian summer monsoon (Zhang et al., 2010 ), with the average wind speed of $5.6 \mathrm{~m} \mathrm{~s}^{-1}$ in the summer of 2015. During the study period, the average temperature, relative humidity, and wind speed are $28.4{ }^{\circ} \mathrm{C}, 51.7 \%$, and $6.3 \mathrm{~m} \mathrm{~s}^{-1}$, respectively, indicating typical summertime meteorological conditions. During the summer of 2015, the average $\mathrm{PM}_{2.5}$ concentration is $56.1 \mu \mathrm{g} \mathrm{m}^{-3}$ and the average $\mathrm{O}_{3}$ concentration in the afternoon is $216.4 \mu \mathrm{g} \mathrm{m}^{-3}$ (Fig.S1de). The high $\mathrm{O}_{3}$ and $\mathrm{PM}_{2.5}$ event occurs frequently during the summertime of 2015, so the study period can well represent the summertime $\mathrm{O}_{3}$ and $\mathrm{PM}_{2.5}$ pollution in Beijing, and provide a suitable case for observation analyses and model simulations to investigate the effect of trans-boundary transport on the summertime air quality of Beijing.

The WRF-CHEM model adopts one grid with horizontal resolution of $6 \mathrm{~km}$ and 35 sigma levels in the vertical direction, and the grid cells used for the domain are $200 \times 200$ (Fig. 1). The physical parameterizations include the microphysics scheme of Hong and Lim (2006), the Mellor, Yamada, and Janjic (MYJ) turbulent kinetic energy (TKE) planetary boundary layer scheme (Janjić, 2002), the unified NOAH land-surface model (Chen and Dudhia, 2001), the rapid radiative transfer model (RRTM) long-wave radiation scheme (Mlawer et al., 1997), and the Goddard shortwave parameterization (Suarex and Chou, 1994; Chou and Suarez, 1999; Chou et al., 2001). The NCEP $1^{\circ} \times 1^{\circ}$ reanalysis data are used to obtain the meteorological initial and boundary conditions, and the meteorological simulations are not nudged in the study. The chemical initial and boundary

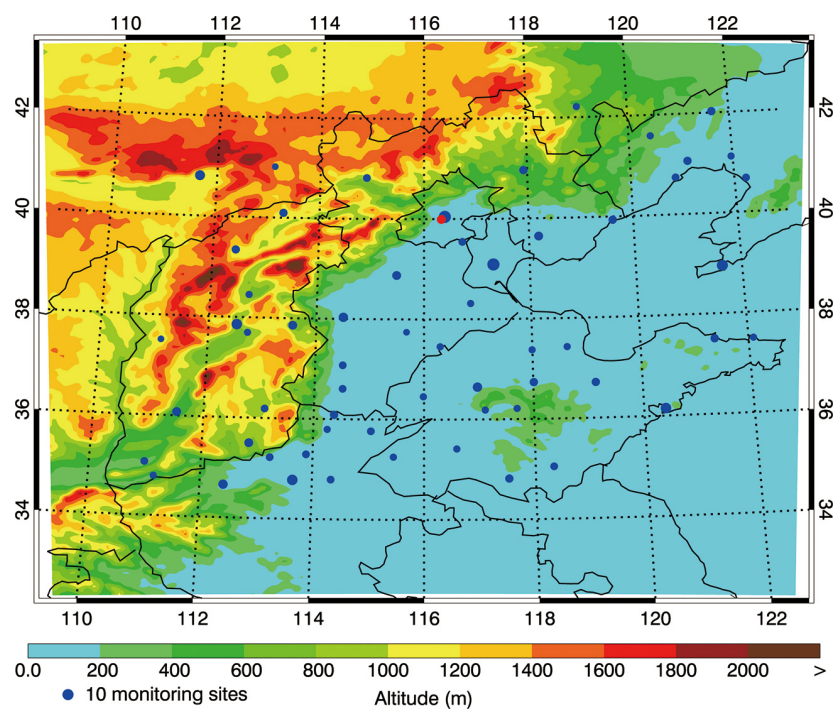

Figure 1. WRF-CHEM simulation domain. The blue circles represent centers of cities with ambient monitoring sites and the red circle denotes the NCNST site. The size of the blue circle denotes the number of ambient monitoring sites of cities.

conditions are interpolated from the $6 \mathrm{~h}$ output of MOZART (Horowitz et al., 2003). The spin-up time of the WRF-CHEM model is $28 \mathrm{~h}$. The SAPRC-99 (Statewide Air Pollution Research Center, version 1999) chemical mechanism is used in the present study.

The anthropogenic emissions are developed by Zhang et al. (2009), whose work is based on the 2013 emission inventory, including contributions from agriculture, industry, power generation, residential, and transportation sources. The $\mathrm{SO}_{2}, \mathrm{NO}_{x}$, and $\mathrm{CO}$ emissions have been adjusted according to their observed trends from 2013 to 2015 in the present study, but the VOC emissions are not changed considering that the VOC emissions are still not fully considered in the current air pollutant control strategy. The major pollutant emissions used in the model simulation for Beijing, Tianjin, and the neighboring provinces (Hebei, Shanxi, and Shandong) are summarized in Table 1. Obviously, high anthropogenic emissions are distributed outside of Beijing, especially in Hebei and Shandong provinces. Figure 2 presents distributions of the emission rates of $\mathrm{VOCs}, \mathrm{NO}_{x}, \mathrm{OC}$, and $\mathrm{SO}_{2}$ in the simulation domain, showing that the anthropogenic emissions are generally concentrated in urban areas. As shown in Fig. 2, the total emissions from neighboring regions are much more than those in Beijing, and the emission rates in Tianjin, the south of Hebei and Shandong are also higher than those in Beijing, particularly with regard to $\mathrm{SO}_{2}$ emissions. Therefore, when the south or east wind is prevailing in the NCP, the severe air pollution can be formed in Beijing when precursor emissions in highly industrialized areas chemically react as they are carried toward Beijing, blocked by mountains and further accumulated and interacted with 
Table 1. Emissions of major anthropogenic species in July 2013 (Unit: $10^{6} \mathrm{~g} \mathrm{month}^{-1}$ ).

\begin{tabular}{lrrrrrr}
\hline Region & $\mathrm{VOC}$ & $\mathrm{NO}_{x}$ & $\mathrm{OC}$ & $\mathrm{SO}_{2}$ & $\mathrm{CO}$ & $\mathrm{PM}_{2.5}$ \\
\hline Beijing Municipality & 29303 & 26272 & 976 & 8796 & 119254 & 5319 \\
Tianjin Municipality & 29255 & 34534 & 1424 & 23204 & 181940 & 8831 \\
Hebei Province & 101710 & 190352 & 12732 & 136957 & 1239510 & 67877 \\
Shanxi Province & 35933 & 93069 & 6381 & 131758 & 355823 & 36473 \\
Shandong Province & 246538 & 235485 & 12181 & 246538 & 937528 & 77681 \\
\hline
\end{tabular}
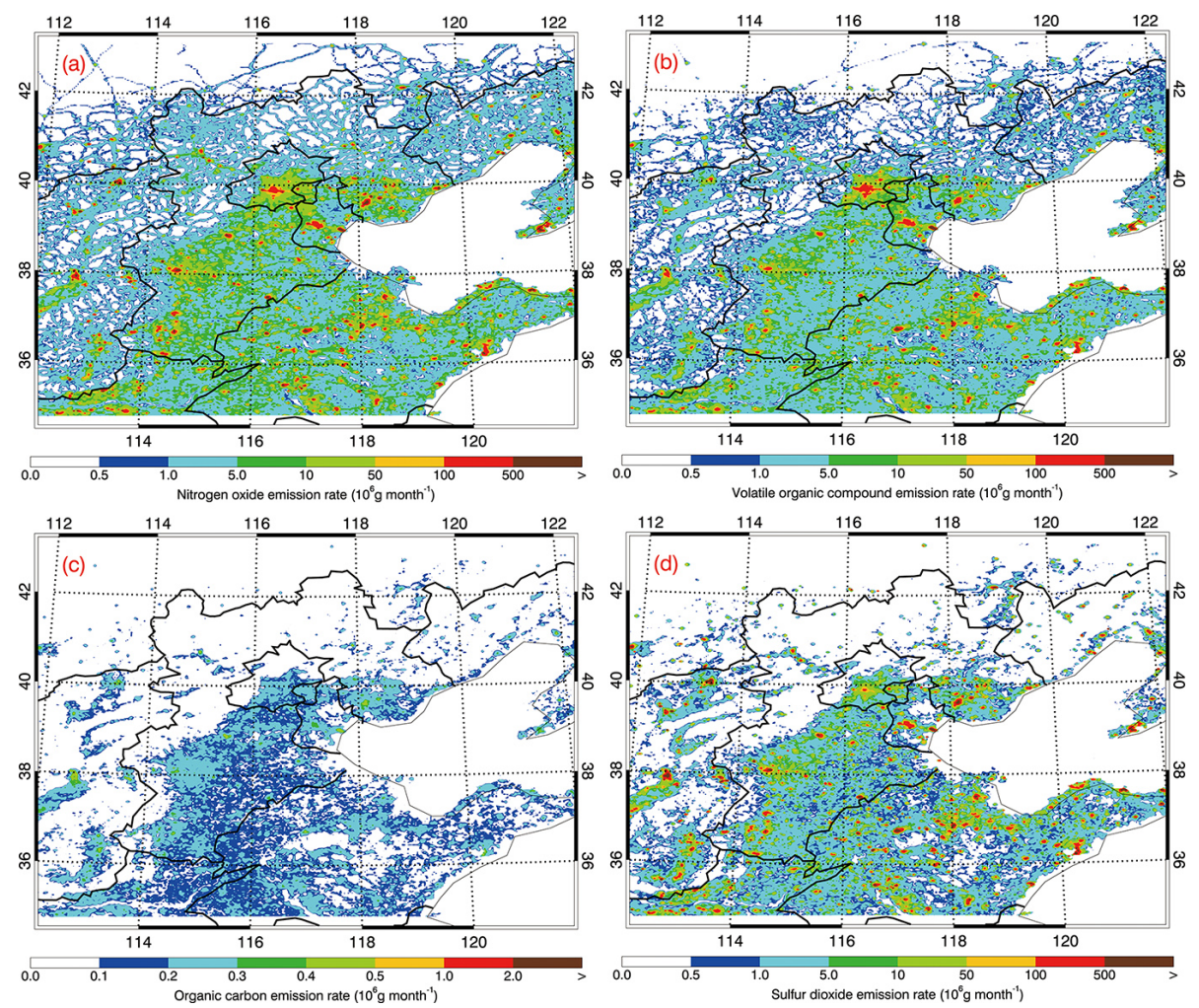

Figure 2. Spatial distribution of anthropogenic (a) $\mathrm{NO}_{x}$, (b) $\mathrm{VOC}_{s}$, (c) $\mathrm{OC}$, and (d) $\mathrm{SO}_{2}$ emission rates $\left(\mathrm{g}\right.$ month ${ }^{-1}$ ) in the simulation domain.

those in Beijing. It is worth noting that uncertainties of the emission inventory used in the study are still rather large considering the rapid changes in anthropogenic emissions that are not fully reflected in the current emission inventories, particularly since implementation of the APPCAP, and the complexity of pollutants precursors. For example, different VOC types exhibit distinct kinetic behaviors, and as an important fraction of total VOCs in the urban atmosphere, aromatics are responsible for the photochemical ozone production and secondary organic aerosol formation (Suh et al., 2003; Fan et al., 2004). In the SAPRC99, aromatics are lumped into ARO1 and ARO2. ARO1 mainly includes toluene, benzene, ethylbenzene, and other aromatics with reaction rate with $\mathrm{OH}(\mathrm{kOH})$ less than $2 \times 10^{4} \mathrm{ppm}^{-1} \mathrm{~min}^{-1}$. ARO2 includes xylene, trimethylbenzene, and other aromatics with $\mathrm{kOH}$ greater than $2 \times 10^{4} \mathrm{ppm}^{-1} \mathrm{~min}^{-1}$. Additionally, bio- genic VOCs also play a considerable role in the ozone production (Li et al., 2007), and monoterpenes and isoprene are the main biogenic VOCs in the SAPRC99 chemical mechanism. The biogenic emissions are calculated online using the MEGAN (Model of Emissions of Gases and Aerosol from Nature) model developed by Guenther et al. (2006).

\subsection{Factor separation approach}

The formation of the secondary atmospheric pollutant, such as $\mathrm{O}_{3}$, secondary organic aerosol, and nitrate, is a complicated nonlinear process in which its precursors from various emission sources and transport react chemically or reach equilibrium thermodynamically. Nevertheless, it is not straightforward to evaluate the contributions from different factors in a nonlinear process. The factor separation approach 
(FSA) proposed by Stein and Alpert (1993) can be used to isolate the effect of one single factor from a nonlinear process and has been widely used to evaluate source effects (Gabusi et al., 2008; Weinroth et al., 2008; Carnevale et al., 2010; Li et al., 2014). The total effect of one factor in the presence of others can be decomposed into contributions from the factor and that from the interactions of all those factors.

Suppose that field $f$ depends on a factor $\varphi$ :

$f=f(\varphi)$

The FSA decomposes function $f(\varphi)$ into a constant part that does not depend on $\varphi(f(0))$ and a $\varphi$-depending component $\left(f^{\prime}(\varphi)\right)$, as follows:

$f^{\prime}(0)=f(0$,

$f^{\prime}(\varphi)=f(\varphi)-f(0)$,

considering that there are two factors $X$ and $Y$ that influence the formation of secondary pollutants in the atmosphere and also interact with each other. Denoting $f_{X Y}, f_{X}, f_{Y}$, and $f_{0}$ as the simulations including both of the two factors, factor $X$ only, factor $Y$ only, and neither of the two factors, respectively. The contributions of factor $X$ and $Y$ can be isolated as follows:

$f_{X}^{\prime}=f_{X}-f_{0}$,

$f_{Y}^{\prime}=f_{Y}-f_{0}$.

Note that term $f_{X(Y)}{ }^{\prime}$ represents the impacts of factor $X(Y)$, while $f_{0}$ is the term independent of factors $X$ and $Y$.

The simulation including both factors $X$ and $Y$ is given by the following:

$f_{X Y}=f_{0}+f_{X}{ }^{\prime}+f_{Y}{ }^{\prime}+f_{X Y^{\prime}}$.

The mutual interaction between $X$ and $Y$ can be expressed as follows:

$$
\begin{gathered}
f_{X Y}{ }^{\prime}=f_{X Y}-f_{0}-f_{X}{ }^{\prime}-f_{Y}{ }^{\prime}=f_{X Y}-\left(f_{X}-f_{0}\right) \\
-\left(f_{Y}-f_{0}\right)-f_{0}=f_{X Y}-f_{X}-f_{Y}+f_{0} .
\end{gathered}
$$

The above equation shows that the study needs four simulations, $f_{X Y}, f_{X}, f_{Y}$, and $f_{0}$, to evaluate the contributions of two factors and their synergistic interactions.

\subsection{Statistical metrics for observation-model comparisons}

In the present study, the mean bias (MB), root mean square error (RMSE), and index of agreement (IOA) are used as indicators to evaluate the performance of WRF-CEHM model in simulation against measurements. IOA describes the relative difference between the model and observation, ranging from 0 to 1 , with 1 indicating perfect agreement.

$$
\begin{aligned}
& \mathrm{MB}=\frac{1}{N} \sum_{i=1}^{N}\left(P_{i}-O_{i}\right), \\
& \mathrm{RMSE}=\left[\frac{1}{N} \sum_{i=1}^{N}\left(P_{i}-O_{i}\right)^{2}\right]^{\frac{1}{2}}, \\
& \mathrm{IOA}=1-\frac{\sum_{i=1}^{N}\left(P_{i}-O_{i}\right)^{2}}{\sum_{i=1}^{N}\left(\left|P_{i}-\bar{O}\right|+\left|O_{i}-\bar{O}\right|\right)^{2}},
\end{aligned}
$$

where $P_{i}$ and $O_{i}$ are the predicted and observed pollutant concentrations, respectively. $N$ is the total number of the predictions used for comparisons, and $\bar{P}$ and $\bar{O}$ represent the average of the prediction and observation, respectively.

\subsection{Pollutant measurements}

The hourly measurements of $\mathrm{O}_{3}, \mathrm{NO}_{2}$, and $\mathrm{PM}_{2.5}$ used in the study are downloaded from the website http://www.aqistudy. $\mathrm{cn} /$. The submicron sulfate, nitrate, ammonium, and organic aerosols are observed by the Aerodyne Aerosol Chemical Speciation Monitor (ACSM), which is deployed at the National Center for Nanoscience and Technology (NCNST), Chinese Academy of Sciences, Beijing (Fig. 1). The mass spectra of organic aerosols are analyzed using the positive matrix factorization (PMF) technique to separate them into four components: hydrocarbon-like organic aerosol (HOA), cooking organic aerosol (COA), coal combustion organic aerosol (CCOA), and oxygenated organic aerosol (OOA). HOA, COA, and CCOA are interpreted as surrogates of primary organic aerosol (POA), and OOA is a surrogate of SOA.

The APPCAP has been implemented since 2013 September, so comparisons of summertime pollutants between 2013 and 2015 can show the mitigation effects on the air quality. Considering that high $\mathrm{O}_{3}$ concentrations generally take place in the afternoon during summertime, Table 2 presents the summertime concentrations of pollutants in the afternoon (12:00-18:00 Beijing Time (BJT)) averaged at 12 monitoring sites in Beijing in 2013 and 2015. The rainy days during summertime in Beijing are 43 and 46 days in 2013 and 2015, respectively, showing the similar meteorological conditions between the 2 years. Therefore, in general, the air pollutant variations between 2013 and 2015 can be mainly attributed to implementation of the APPCAP. Apparently, implementation of the APPCAP has considerably decreased the concentrations of primary species of $\mathrm{CO}$ and $\mathrm{SO}_{2}$, particularly with regard to $\mathrm{SO}_{2}$, which was reduced by more than $40 \%$ from 2013 to 2015. Most $\mathrm{NO}_{x}$ exists in the form of $\mathrm{NO}_{2}$ in the afternoon during summertime due to active photochemical processes. Therefore, a $25.1 \%$ decrease of $\mathrm{NO}_{2}$ in the afternoon from 2013 to 2015 shows that the $\mathrm{NO}_{x}$ emission mitigation is also effective in Beijing. The $\mathrm{PM}_{2.5}$ concen- 
Table 2. Hourly mass concentrations of pollutants averaged in the afternoon at 12 monitoring sites in Beijing during summertime of 2013 and 2015 .

\begin{tabular}{lrrrrr}
\hline Pollutants & $\mathrm{CO}\left(\mathrm{mg} \mathrm{m}^{-3}\right)$ & $\mathrm{SO}_{2}\left(\mu \mathrm{g} \mathrm{m}^{-3}\right)$ & $\mathrm{NO}_{2}\left(\mu \mathrm{g} \mathrm{m}^{-3}\right)$ & $\mathrm{O}_{3}\left(\mu \mathrm{g} \mathrm{m}^{-3}\right)$ & $\mathrm{PM}_{2.5}\left(\mu \mathrm{g} \mathrm{m}^{-3}\right)$ \\
\hline 2013 & 1.09 & 9.85 & 31.6 & 133.0 & 81.4 \\
2015 & 0.88 & 5.71 & 23.6 & 163.2 & 61.9 \\
Change (\%) & -20.0 & -42.0 & -25.1 & +22.8 & -24.0 \\
\hline
\end{tabular}

trations decreased by about $24.0 \%$ from 2013 to 2015 , approaching the expected $25 \%$ reduction by 2017 relative to 2012 levels. However, the $\mathrm{O}_{3}$ trend is not anticipated in Beijing, and $\mathrm{O}_{3}$ concentrations increased from $133.0 \mu \mathrm{g} \mathrm{m}^{-3}$ in 2013 to $163.2 \mu \mathrm{g} \mathrm{m}^{-3}$ in 2015 , enhanced by $22.8 \%$. For the discussion convenience, we have defined the $\mathrm{O}_{3}$ exceedance with hourly $\mathrm{O}_{3}$ concentrations exceeding $200 \mu \mathrm{g} \mathrm{m}^{-3}$ and $\mathrm{PM}_{2.5}$ exceedance with hourly $\mathrm{PM}_{2.5}$ concentrations exceeding $75 \mu \mathrm{g} \mathrm{m}^{-3}$. Although the $\mathrm{PM}_{2.5}$ exceedance frequency in the afternoon has decreased by $25.0 \%$ from 2013 to 2015, but still remained at $32.7 \%$ in 2015 . The $\mathrm{O}_{3}$ exceedance frequency in 2015 is $31.8 \%$, enhanced by $57.6 \%$ compared to $20.2 \%$ in 2013. Hence, during the summertime of 2015, 2 years after implementation of the APPCAP, Beijing still frequently experienced high $\mathrm{O}_{3}$ and/or $\mathrm{PM}_{2.5}$ pollution.

\section{Results and discussions}

\subsection{Model performance}

The hourly measurements of $\mathrm{O}_{3}, \mathrm{NO}_{2}$, and $\mathrm{PM}_{2.5}$ in $\mathrm{BTH}$ and ACSM-measured aerosol species in Beijing are used to validate the WRF-CHEM model simulations.

\subsection{1 $\mathrm{O}_{3}, \mathrm{NO}_{2}$, and $\mathrm{PM}_{2.5}$ simulations in Beijing}

Figure 3 shows the temporal variations of observed and simulated near-surface $\mathrm{O}_{3}, \mathrm{NO}_{2}$, and $\mathrm{PM}_{2.5}$ concentrations averaged over monitoring sites in Beijing from 5 to 14 July 2015. The WRF-CHEM model performs reasonably well in simulating the $\mathrm{PM}_{2.5}$ variations compared with observations in Beijing. The MB and RMSE are -3.6 and $22.5 \mu \mathrm{g} \mathrm{m}^{-3}$, respectively, and the IOA is 0.86 . The model reproduces well the temporal variations of $\mathrm{O}_{3}$ concentrations, with an IOA of 0.92 . The model considerably underestimates the $\mathrm{O}_{3}$ concentration during daytime on 5, 6, and 13 July. Most of the monitoring sites in Beijing are concentrated in urban areas. Therefore, if the simulated winds cause the $\mathrm{O}_{3}$ plume formed in the urban area to leave early or deviate the $\mathrm{O}_{3}$ plume transported from outside of Beijing from the urban area, the model is subject to underestimating the $\mathrm{O}_{3}$ concentration in Beijing (Bei et al., 2010). The WRF-CHEM model also reasonably yields the $\mathrm{NO}_{2}$ diurnal profiles, but frequently overestimates the $\mathrm{NO}_{2}$ concentrations during nighttime, which is likely caused by the biased boundary layer simulations.
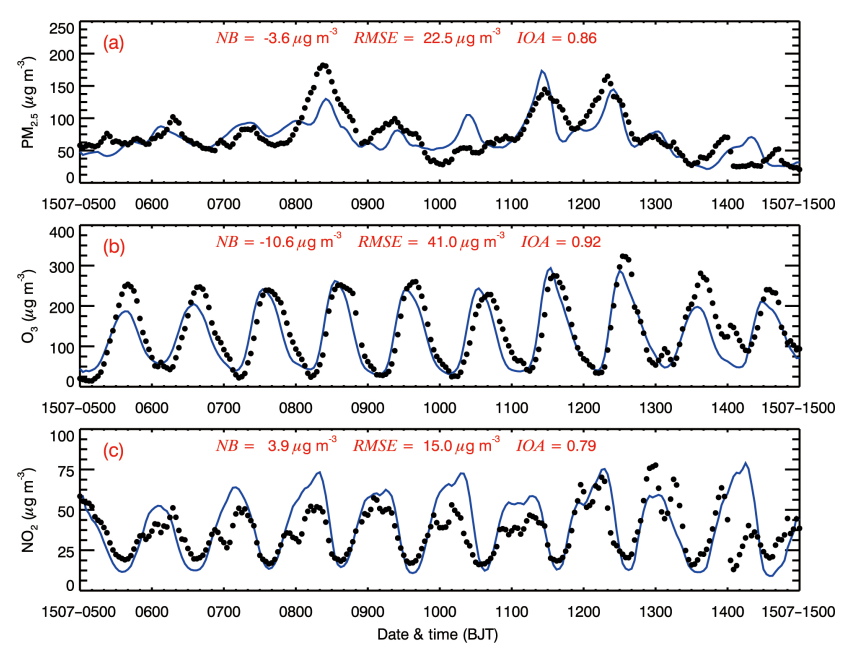

Figure 3. Comparison of measured (black dots) and predicted (blue line) diurnal profiles of near-surface hourly (a) $\mathrm{PM}_{2.5}$, (b) $\mathrm{O}_{3}$, and (c) $\mathrm{NO}_{2}$ averaged over all ambient monitoring stations in Beijing from 5 to 14 July 2015 .

\subsubsection{Aerosol species simulations in Beijing}

Figure 4 shows the temporal variations of simulated and observed aerosol species at NCNST site in Beijing from 5 to 14 July 2015 . The WRF-CHEM model generally performs reasonably in simulating the aerosol species variations compared with ACSM measurements. As a primary aerosol species, the POA in Beijing is determined by direct emissions from various sources and transport from outside of Beijing, so uncertainties from emissions and meteorological fields have a remarkable effect on the model simulations (Bei et al., 2012, 2013). Although the MB and RMSE for POA are 0.0 and $3.1 \mu \mathrm{g} \mathrm{m}^{-3}$, respectively, the IOA is less than 0.60 , indicating the considerable biases in POA simulations. The WRF-CHEM model has difficulties in simulating well the sulfate aerosol, with an IOA lower than 0.60 . The model cannot produce the observed high peaks of sulfate aerosols around noontime on 8, 11, and 12 July 2015. The sulfate aerosol in the atmosphere is produced from multiple sources, including $\mathrm{SO}_{2}$ gas-phase oxidations by hydroxyl radicals $(\mathrm{OH})$ and stabilized Criegee intermediates $(\mathrm{sCI})$, aqueous reactions in cloud or fog droplets, and heterogeneous reactions on aerosol surfaces, as well as direct emissions from power plants and industries (Li et al., 2016). 


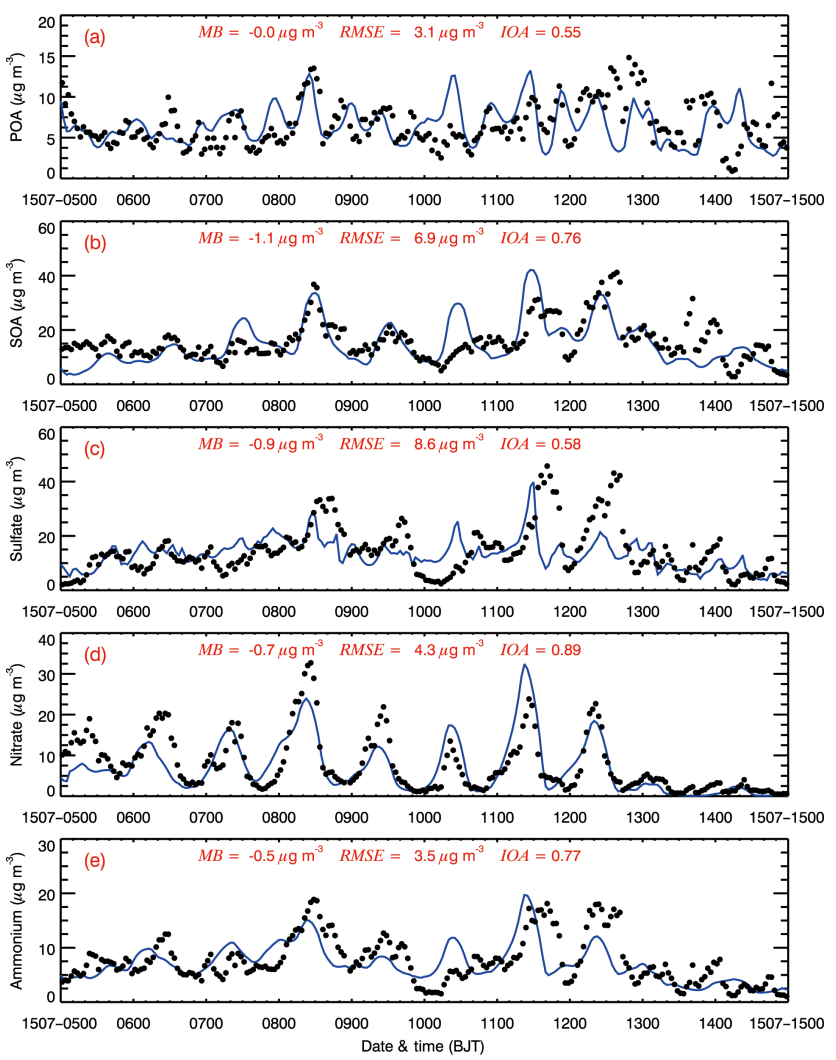

Figure 4. Comparison of measured (black dots) and simulated (black line) diurnal profiles of submicron aerosol species of (a) POA, (b) SOA, (c) sulfate, (d) nitrate, and (e) ammonium at NCNST site in Beijing from 5 to 14 July 2015.

The model reproduces reasonably well the observed temporal variations of SOA, nitrate, and ammonium, with IOAs exceeding 0.75 . The model simulates well the peak concentration of SOA, nitrate and ammonium at the rush hour, but the model also underestimates the SOA, nitrate, and ammonium as well, with $\mathrm{MB}$ of $-1.1,-0.7$, and $-0.5 \mu \mathrm{g} \mathrm{m}^{-3}$, respectively. For nitrate and ammonium, the underestimates occur mainly on 8 July 2015 , possibly due to wind fields, which will be further analyzed in the Supplement (Fig. S2).

\subsection{3 $\mathrm{O}_{3}, \mathrm{NO}_{2}$, and $\mathrm{PM}_{2.5}$ simulations in $\mathrm{BTH}$}

Figure 5 shows the diurnal profiles of observed and simulated near-surface $\mathrm{O}_{3}, \mathrm{NO}_{2}$, and $\mathrm{PM}_{2.5}$ concentrations averaged over monitoring sites in BTH from 5 to 14 July 2015. The WRF-CHEM model exhibits good performance in predicting the temporal variations of $\mathrm{O}_{3}, \mathrm{NO}_{2}$, and $\mathrm{PM}_{2.5}$ concentrations compared with measurements in BTH, with IOAs higher than 0.80. In addition, $\mathrm{O}_{3}$ and $\mathrm{NO}_{2}$ simulations are also improved in BTH compared to those in Beijing, indicating better model performance for regional simulations on a large scale.
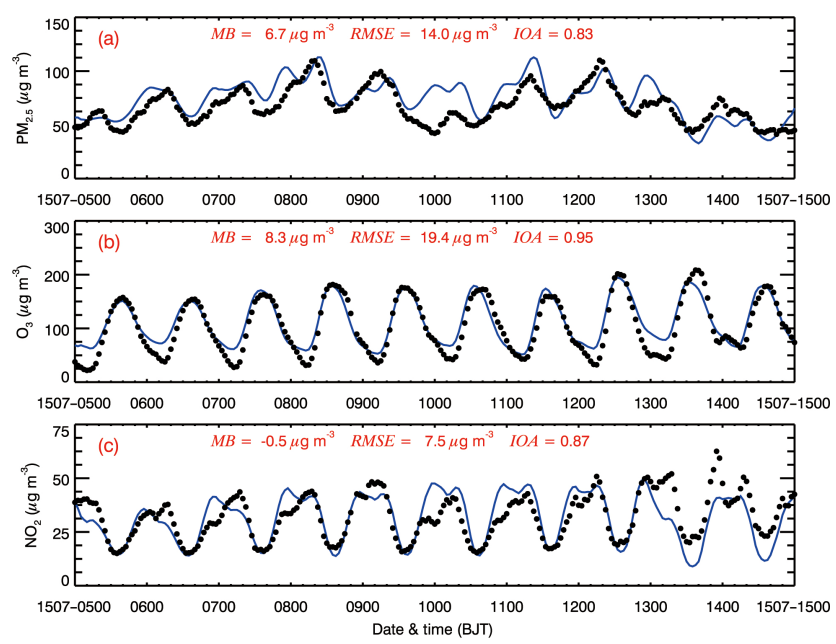

Figure 5. Comparison of measured (black dots) and predicted (blue line) diurnal profiles of near-surface hourly (a) $\mathrm{PM}_{2.5}$, (b) $\mathrm{O}_{3}$, and (c) $\mathrm{NO}_{2}$ averaged over all ambient monitoring stations in $\mathrm{BTH}$ from 5 to 14 July 2015 .

Figure 6 presents the distributions of calculated and observed near-surface $\mathrm{PM}_{2.5}$ concentrations along with the simulated wind fields at 10:00 BJT on the 6 selected representative days with high $\mathrm{O}_{3}$ and $\mathrm{PM}_{2.5}$ concentrations. The calculated $\mathrm{PM}_{2.5}$ spatial patterns generally agree well with the observations at the monitoring sites. The observed $\mathrm{PM}_{2.5}$ concentrations in BTH are still high even after implementation of the APPCAP, frequently exceeding $75 \mu \mathrm{g} \mathrm{m}^{-3}$ on the selected 6 days. The $\mathrm{PM}_{2.5}$ concentrations in Beijing are higher than $115 \mu \mathrm{g} \mathrm{m}^{-3}$ at 10:00 BJT on 8,11 , and 12 July 2015, causing moderate air pollution.

The $\mathrm{O}_{3}$ concentration during summertime reaches its peak during the period from 14:00 to 16:00 BJT in Beijing (Tang et al., 2012). Figure 7 presents the spatial distribution of calculated and measured near-surface $\mathrm{O}_{3}$ concentration at 15:00 BJT on the selected 6 days, along with the simulated wind fields. In general, the simulated $\mathrm{O}_{3}$ spatial patterns are consistent with the measurements, but model biases still exist. High $\mathrm{O}_{3}$ concentrations at 15:00 BJT in Beijing are observed and also simulated by the model, frequently exceeding $250 \mu \mathrm{g} \mathrm{m}^{-3}$. The $\mathrm{O}_{3}$ transport to Beijing from its surrounding areas is also obvious when the winds are easterly or southerly. Figure 8 provides the spatial distribution of simulated and observed near-surface $\mathrm{NO}_{2}$ concentration on the selected 6 days at 08:00 BJT when the $\mathrm{NO}_{2}$ concentration reaches it peak due to rush hour $\mathrm{NO}_{x}$ emissions and a low planetary boundary layer (PBL). The simulated near-surface $\mathrm{NO}_{2}$ concentrations highlight the dominant impact of the anthropogenic emissions, primarily concentrated in cities or their downwind areas, which generally agree well with the measurements. Beijing is surrounded from south to east by cities with high $\mathrm{NO}_{2}$ concentrations, which can influence the 


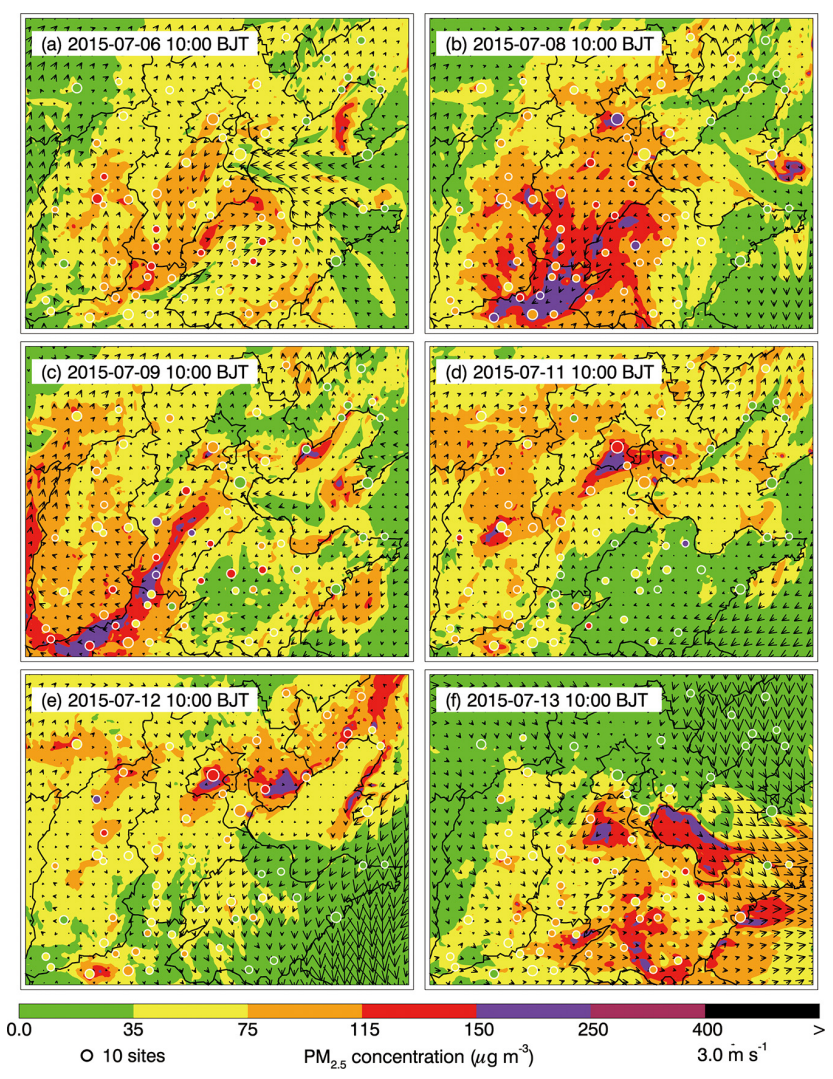

Figure 6. Pattern comparison of simulated vs. observed nearsurface $\mathrm{PM}_{2.5}$ at 10:00 BJT during the selected periods from 5 to 14 July 2015. Colored circles: $\mathrm{PM}_{2.5}$ observations; color contour: $\mathrm{PM}_{2.5}$ simulations; black arrows: simulated surface winds.

$\mathrm{O}_{3}$ formation in Beijing when south or east winds are prevalent.

The good agreements between predicted $\mathrm{PM}_{2.5}, \mathrm{O}_{3}, \mathrm{NO}_{x}$, and aerosol species and the corresponding measurements show that the modeled meteorological fields and emissions used in simulations are generally reasonable.

\subsection{Contributions of trans-boundary transport to the $\mathrm{O}_{3}$ and $\mathrm{PM}_{2.5}$ levels in Beijing}

\subsubsection{Analysis of horizontal transport of $\mathrm{O}_{3}$ and $\mathrm{PM}_{2.5}$}

The analysis in Sect. 3.1.3 has shown the strong correlation between the airflow and the high level of pollutants in Beijing during the study episode. It is essential to confirm whether the continuous air pollution in Beijing is directly related to the airflow transport from outside of Beijing (An et al., 2007; Yang et al., 2010). In the present study, the horizontal transport flux intensity is defined as the horizontal wind speed on the grid border multiplied by the pollutant concentration of the corresponding grid from which the airflows come (Jiang et al., 2008). Considering that transboundary transport mainly occurs within the PBL, the study
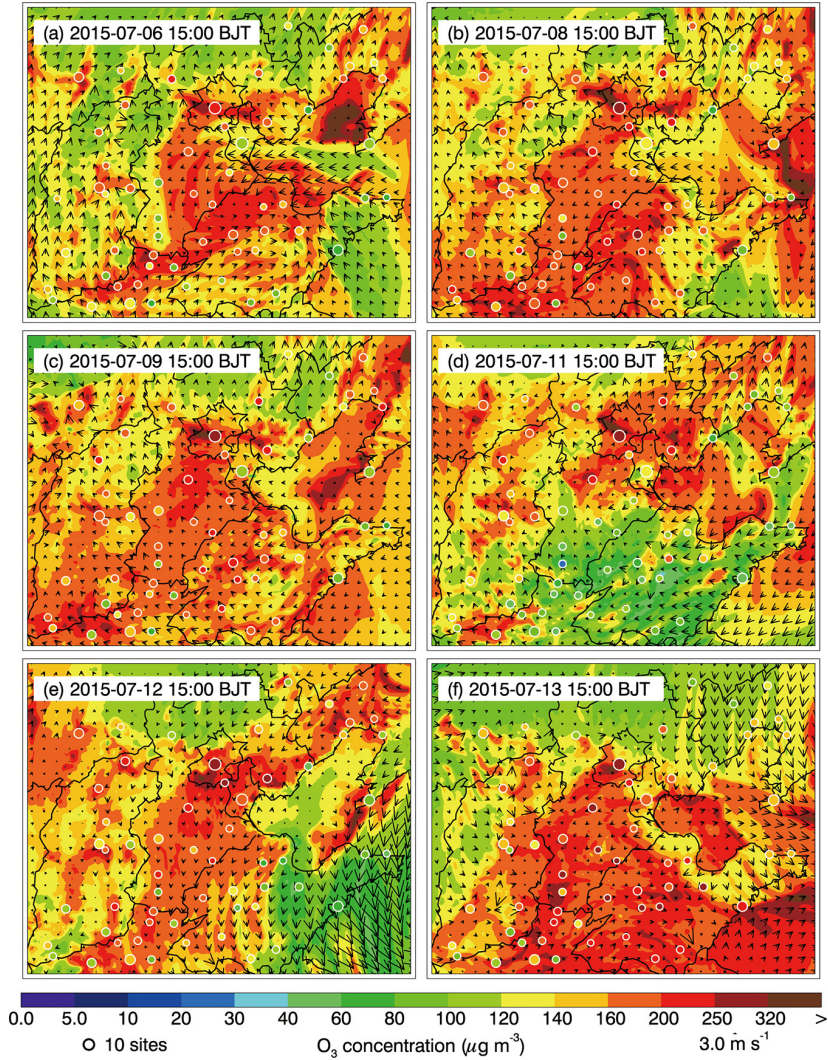

Figure 7. Same as Fig. 6, but for $\mathrm{O}_{3}$ at 15:00 BJT.

also focuses on the contribution of trans-boundary transport of pollutants within the PBL over Beijing and its surrounding areas. Previous studies have shown that the average mixing layer height is approximately between 600 and $800 \mathrm{~m}$ during summertime, with the maximum during noontime higher than $1000 \mathrm{~m}$ (H. Wang et al., 2015; Tang et al., 2016). Figure 9 shows the temporal variations of net horizontal transport flux of $\mathrm{PM}_{2.5}, \mathrm{O}_{3}$, and $\mathrm{NO}_{2}$ through the Beijing boundary and the pollutant contributions from non-Beijing emissions to the air quality in Beijing city. The hourly $\mathrm{PM}_{2.5}, \mathrm{O}_{3}$, and $\mathrm{NO}_{2}$ contributions of non-Beijing emissions generally have the same variation trend as the horizontal transport flux, indicating that the contribution of surrounding sources plays an important role in high pollutant concentrations in Beijing during the study episode. For example, the $\mathrm{O}_{3}$ net flux also has the similar peak in the afternoon as the $\mathrm{O}_{3}$ contribution from the non-Beijing emissions. As discussed in Sect. 3.1.3, the prevailing south wind dominates in BTH, so the largest flux intensities are from the south, with the average of 103.3 and $244.5 \mathrm{~g} \mathrm{~s}^{-1}$ for $\mathrm{PM}_{2.5}$ and $\mathrm{O}_{3}$, respectively (Table $\mathrm{S} 1$ ), indicating that the pollutants are mainly from the south. It should be noted that the flux of $\mathrm{O}_{3}$ is mainly focused in the afternoon from 12:00 to 18:00 BJT. The average net horizontal transport fluxes for $\mathrm{PM}_{2.5}$ and $\mathrm{O}_{3}$ during the episode are 


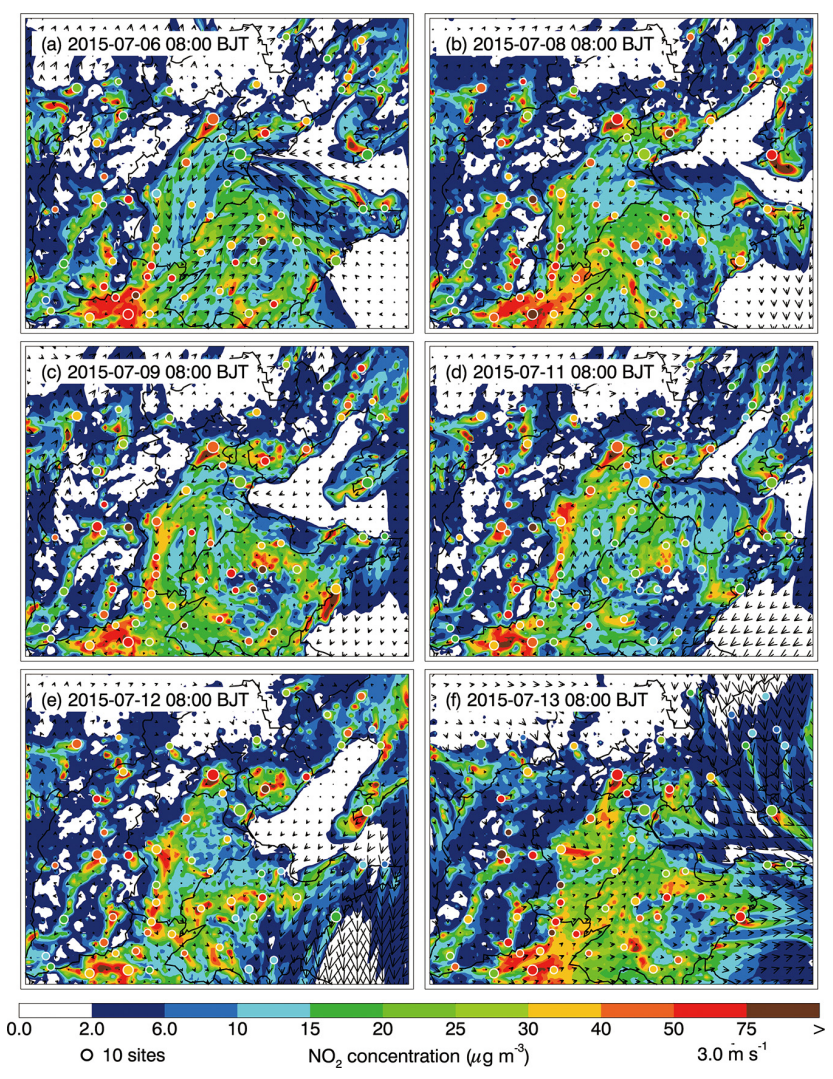

Figure 8. Same as Fig. 6, but for $\mathrm{NO}_{2}$ at 08:00 BJT.

68.2 and $68.5 \mathrm{~g} \mathrm{~s}^{-1}$, respectively, showing important contributions of non-Beijing emissions to the air quality in Beijing.

\subsubsection{Trans-boundary transport contributions to $\mathrm{O}_{3}$ in Beijing}

The FSA is used in the present study to evaluate the contributions and interactions of emissions from Beijing and outside of Beijing to the near-surface concentrations of $\mathrm{O}_{3}$ and $\mathrm{PM}_{2.5}$ in Beijing. Four model simulations are performed, including $f_{\mathrm{BS}}$ with both the anthropogenic emissions from Beijing and outside of Beijing, $f_{\mathrm{B}}$ with the emission from Beijing alone, $f_{\mathrm{S}}$ with only emissions outside of Beijing, and $f_{0}$ without both the emissions from Beijing and outside of Beijing, representing background concentrations. Apparently, the air pollutant levels in Beijing are determined by the contribution from local emissions $\left(f_{\mathrm{B}}{ }^{\prime}, f_{\mathrm{B}}-f_{0}\right)$, the trans-boundary transport of non-Beijing emissions $\left(f_{\mathrm{S}}{ }^{\prime}, f_{\mathrm{S}}-f_{0}\right)$, emission interactions between local and non-Beijing emissions $\left(f_{\mathrm{BS}}{ }^{\prime}\right.$, $\left.f_{\mathrm{BS}}-f_{\mathrm{B}}-f_{\mathrm{S}}+f_{0}\right)$, and background $\left(f_{0}\right)$.

Figure 10 provides the temporal variations of the average near-surface $\mathrm{O}_{3}$ and $\mathrm{PM}_{2.5}$ concentrations from $f_{\mathrm{BS}}$ with all the emissions, $f_{\mathrm{B}}$ with Beijing emissions alone, and $f_{\mathrm{S}}$ with non-Beijing emissions alone in Beijing from 5 to 14 July 2015. Apparently, non-Beijing emissions generally play a more important role in the $\mathrm{O}_{3}$ level of Beijing than local
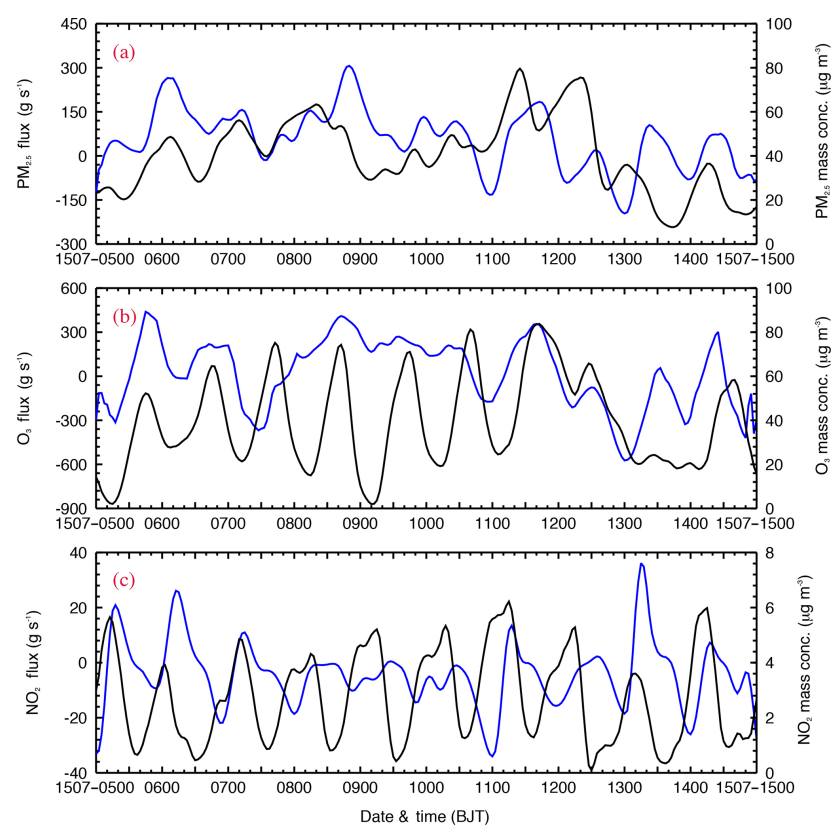

Figure 9. Temporal variations of total net horizontal transport flux of $\mathrm{PM}_{2.5}, \mathrm{O}_{3}$, and $\mathrm{NO}_{2}$ over the Beijing boundary (blue line) and the contribution of non-Beijing emission to the $\mathrm{PM}_{2.5}, \mathrm{O}_{3}$, and $\mathrm{NO}_{2}$ concentrations in Beijing (black line) during the study episode.

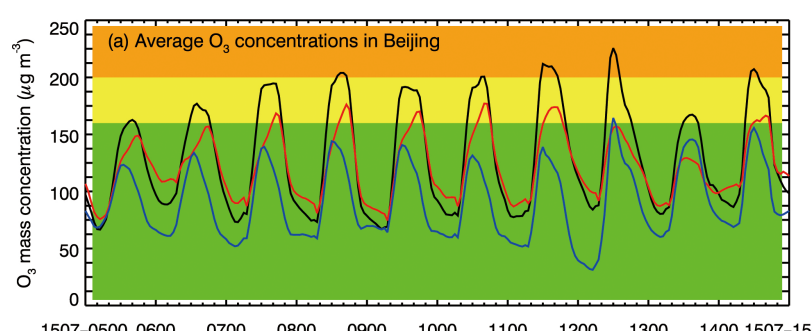

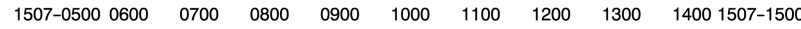

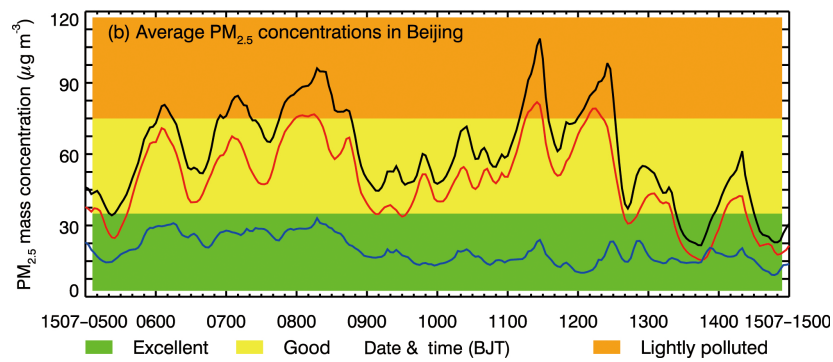

Figure 10. Temporal variations of the average near-surface $\mathrm{O}_{3}$ and $\mathrm{PM}_{2.5}$ concentrations from $f_{\mathrm{BS}}$ with all the emissions (black line), $f_{\mathrm{B}}$ with Beijing emissions alone (blue line), and $f_{\mathrm{S}}$ with nonBeijing emissions alone (red line) in Beijing from 5 to 14 July 2015.

emissions. Even when the Beijing local emissions are excluded, the $\mathrm{O}_{3}$ concentration in Beijing still remains at a high level, with an average of $153 \mu \mathrm{g} \mathrm{m}^{-3}$ and ranging from 130 to $180 \mu \mathrm{g} \mathrm{m}^{-3}$ in the afternoon. When only considering the Beijing local emission in simulations, the afternoon average $\mathrm{O}_{3}$ concentration in Beijing is approximately $126.6 \mu \mathrm{g} \mathrm{m}^{-3}$, 
Table 3. Average $\mathrm{O}_{3}$ contributions (\%) from 12:00 to 18:00 BJT in Beijing from local and non-Beijing emissions, as well as the background emissions and interactions of both emissions from 5 to 14 July 2015.

\begin{tabular}{lrrrr}
\hline Emissions & Beijing & Surroundings & Background & Interactions \\
\hline Date & $f_{\mathrm{B}^{\prime}}$ & $f_{\mathrm{S}^{\prime}}$ & $f_{\mathrm{BS}}{ }^{\prime}$ & $f_{0}$ \\
\hline 5 & 15.5 & 26.1 & -2.4 & 60.8 \\
6 & 19.8 & 30.9 & -3.0 & 52.3 \\
7 & 25.5 & 36.0 & -3.6 & 42.1 \\
8 & 27.0 & 36.9 & -5.9 & 42.0 \\
9 & 23.2 & 35.3 & -4.6 & 46.1 \\
10 & 18.6 & 39.9 & -2.6 & 44.1 \\
11 & 29.4 & 48.0 & -10.0 & 32.6 \\
12 & 35.4 & 40.6 & -11.4 & 35.4 \\
13 & 23.4 & 15.2 & -1.5 & 62.9 \\
14 & 20.3 & 32.2 & -3.3 & 50.8 \\
\hline Average & 22.4 & 36.6 & -5.1 & 46.1 \\
\hline
\end{tabular}

varying from 80 to $160 \mu \mathrm{g} \mathrm{m}^{-3}$. On $13 \mathrm{July}$, the contribution from Beijing local emissions exceeds that from non-Beijing emissions because north winds are prevailing, bringing clean air to Beijing (Fig. 7f). Table 3 gives the average $\mathrm{O}_{3}$ contributions from 12:00 to 18:00 BJT in Beijing from local emissions, non-Beijing emissions, emission interactions, and background. The local emissions contribute about $22.4 \%$ on average in the afternoon to the $\mathrm{O}_{3}$ level in Beijing, varying from 15.5 to $35.4 \%$. The non-Beijing emissions contribute more than local sources, with an average contribution of $36.6 \%$, ranging from 15.2 to $48.0 \%$. The emission interactions in Beijing decrease the $\mathrm{O}_{3}$ level by $5.1 \%$ on average. $\mathrm{O}_{3}$ formation is a nonlinear process, depending not only on the absolute levels of $\mathrm{NO}_{x}$ and VOCs, but also the ratio of $\mathrm{VOC}_{\mathrm{s}} / \mathrm{NO}_{x}$ (Sillman et al., 1990; Lei et al., 2007, 2008). When the $\mathrm{O}_{3}$ precursors emitted from outside of Beijing are transported to Beijing and mixed with local emissions, the concentrations of $\mathrm{O}_{3}$ precursors are increased and the ratio of $\mathrm{VOC}_{\mathrm{s}} / \mathrm{NO}_{x}$ is also altered, causing the formed $\mathrm{O}_{3}$ concentration unequal to the simple linear summation of $\mathrm{O}_{3}$ contributions from the local and non-Beijing emissions. The background $\mathrm{O}_{3}$ in Beijing plays an important role in the $\mathrm{O}_{3}$ level in the afternoon, accounting for $46.1 \%$ of the $\mathrm{O}_{3}$ concentration. The background $\mathrm{O}_{3}$ contribution varies from 32.6 to $62.9 \%$ during the episode, which is primarily determined by the prevailing wind direction. When the northerly wind is prevalent, the clean airflow from the north affects Beijing, enhancing the background $\mathrm{O}_{3}$ contribution, such as on 5, 13, and 14 July 2015 . However, when the polluted airflow from the south impacts Beijing, the background $\mathrm{O}_{3}$ contribution is decreased. The $\mathrm{O}_{3}$ contributions in Beijing induced by the trans-boundary transport of emissions outside of Beijing are about $31.5 \%$ of the $\mathrm{O}_{3}$ concentration during the study episodes, which is in agreement with previous studies (Streets et al., 2007; Wang et al., 2008), indicating that the
Table 4. Average $\mathrm{PM}_{2.5}$ contributions (\%) in Beijing from local and non-Beijing emissions, as well as the interactions of both emissions and background emissions from 5 to 14 July 2015.

\begin{tabular}{lrrrr}
\hline Emissions & Beijing & Surroundings & Interactions & Background \\
\hline Date & $f_{\mathrm{B}}{ }^{\prime}$ & $f_{\mathrm{S}}{ }^{\prime}$ & $f_{\mathrm{BS}^{\prime}}$ & $f_{0}$ \\
\hline 5 & 14.6 & 55.1 & 3.3 & 27.0 \\
6 & 14.9 & 56.3 & 3.4 & 25.4 \\
7 & 14.2 & 56.4 & 8.0 & 21.4 \\
8 & 13.2 & 61.1 & 6.4 & 19.3 \\
9 & 15.3 & 61.3 & 6.3 & 17.1 \\
10 & 11.5 & 66.5 & 6.2 & 15.8 \\
11 & 9.7 & 71.0 & 8.1 & 11.2 \\
12 & 14.2 & 67.6 & 5.6 & 12.6 \\
13 & 19.2 & 47.2 & 3.6 & 30.0 \\
14 & 16.6 & 53.1 & 6.4 & 23.9 \\
\hline Average & 13.7 & 61.5 & 5.9 & 18.9 \\
\hline
\end{tabular}

trans-boundary transport constitutes the main reason for the elevated $\mathrm{O}_{3}$ level in Beijing after implementation of the APPCAP.

Previous studies have proposed that the regional transport of $\mathrm{O}_{3}$ precursors can play an important role in inducing the high $\mathrm{O}_{3}$ concentration level in Beijing (Wang et al., 2009; Zhang et al., 2014). Table $\mathrm{S} 2$ provides the average $\mathrm{NO}_{2}$ contributions in Beijing from local emissions, non-Beijing emissions, emission interactions, and background. Different from $\mathrm{O}_{3}$, the local emissions dominate the level of $\mathrm{NO}_{2}$ in the Beijing area, with an average contribution of $70.3 \%$ during the study episode. The average contribution of non-Beijing emissions, emission interactions, and background are 24.8, 0.9, and $4.0 \%$, respectively.

\subsubsection{Trans-boundary transport contributions to $\mathbf{P M}_{2.5}$ in Beijing}

When the Beijing local emissions are not considered in simulations, Beijing still experiences high $\mathrm{PM}_{2.5}$ pollution, with an average $\mathrm{PM}_{2.5}$ concentration of $48.3 \mu \mathrm{g} \mathrm{m}^{-3}$ during the simulation episode, and the $\mathrm{PM}_{2.5}$ level in Beijing still exceeds $75 \mu \mathrm{g} \mathrm{m}^{-3}$ on several days. However, when only considering the Beijing local emissions, the average $\mathrm{PM}_{2.5}$ concentration in Beijing is $19.6 \mu \mathrm{g} \mathrm{m}^{-3}$ during the episode, showing that Beijing's $\mathrm{PM}_{2.5}$ pollution is dominated by the trans-boundary transport (Fig. 10b). Table 4 shows the average $\mathrm{PM}_{2.5}$ contribution in Beijing from local emissions, nonBeijing emissions, emission interactions, and background. During the study episode, the average $\mathrm{PM}_{2.5}$ contribution from local emissions is $13.7 \%$, which is much lower than the contribution of $61.5 \%$ from non-Beijing emissions, further showing the dominant role of the trans-boundary transport in the Beijing $\mathrm{PM}_{2.5}$ pollution. The emission interactions enhance the $\mathrm{PM}_{2.5}$ level in Beijing on average, with a contribution of $5.9 \%$. The background $\mathrm{PM}_{2.5}$ contribution to Beijing is $18.9 \%$ on average, lower than those for $\mathrm{O}_{3}$. The $\mathrm{PM}_{2.5}$ 
contribution caused by the trans-boundary transport is about $67.4 \%$ of $\mathrm{PM}_{2.5}$ concentrations in Beijing, indicating that the cooperation with neighboring provinces to control the $\mathrm{PM}_{2.5}$ level is key for Beijing to improve air quality. Previous studies have also demonstrated the dominant role of non-Beijing emissions in the $\mathrm{PM}_{2.5}$ level in Beijing. Based on the CMAQ model, Streets et al. (2007) have reported that average contribution of regional transport to $\mathrm{PM}_{2.5}$ at the Olympic Stadium can be $34 \%$, up to $50-70 \%$ under prevailing south winds. Guo et al. (2010) have provided a rough estimation that the regional transport can contribute $69 \%$ of the $\mathrm{PM}_{10}$ and $87 \%$ of the $\mathrm{PM}_{1.8}$ in the Beijing local area using the short and low time resolution data in the summer. Combining the $\mathrm{PM}_{2.5} \mathrm{ob}-$ servations and MM5-CMAQ model results, regional transport is estimated to contribute $54.6 \%$ of the $\mathrm{PM}_{2.5}$ concentration during the polluted period, with an annual average $\mathrm{PM}_{2.5}$ contribution of $42.4 \%$ (Lang et al., 2013). Using the longterm measurements of $\mathrm{PM}_{2.5}$ mass concentrations from 2005 to 2010 at urban Beijing, and trajectory cluster and receptor models, the average contribution of long-distance transport to Beijing's $\mathrm{PM}_{2.5}$ level can be approximately $75.2 \%$ in the summer (L. L. Wang et al., 2015).

\subsubsection{Trans-boundary transport contributions to aerosol species in Beijing}

Figure 11 shows the temporal variation of the averaged contributions to the near-surface aerosol constituents from total emissions $\left(f_{\mathrm{BS}}\right)$, local emissions $\left(f_{\mathrm{B}}{ }^{\prime}\right)$, the trans-boundary transport of non-Beijing emissions $\left(f_{\mathrm{S}}{ }^{\prime}\right)$, emission interactions $\left(f_{\mathrm{BS}}{ }^{\prime}\right)$, and the background $\left(f_{0}\right)$ during the simulation episode. The temporal variations of elemental carbon (EC) and POA from local emissions and trans-boundary transport exhibit obvious diurnal cycles, i.e., highest during nighttime and lowest in the afternoon, corresponding to the variations of PBL height and anthropogenic emissions. The SOA from local emissions reaches its peak in the afternoon when the $\mathrm{O}_{3}$ concentration is high, but the trans-boundary transport causes the gradual accumulation process of SOA in Beijing from 5 to 9 July and from 9 to 13 July. The sulfate temporal profile from the trans-boundary transport is similar to that of SOA, also showing the accumulation process. In addition, the sulfate aerosols from local emissions do not vary remarkably. The nitrate aerosols from local emissions and the transboundary transport generally attain peaks in the morning when the air temperature is not high and the $\mathrm{HNO}_{3}$ concentrations are not low. The ammonium aerosol variations are generally determined by those of sulfate and nitrate aerosols. For example, the variations of ammonium aerosols from the trans-boundary include not only the morning peaks, but also the accumulation processes from 5 to 9 July and from 9 to 13 July. Except for the sulfate aerosol, the temporal variations of aerosol species from background are not large.

Table 5 presents the average aerosol constituent contributions from Beijing local emissions, non-Beijing emissions, emission interactions, and the background, and mass fractions in the total $\mathrm{PM}_{2.5}$ in Beijing during the episode. Organic aerosols $(\mathrm{POA}+\mathrm{SOA})$ constitute the most important component of $\mathrm{PM}_{2.5}$, accounting for $34.8 \%$ of $\mathrm{PM}_{2.5}$ mass concentration, which is consistent with the ACSM measurement in Beijing (Sun et al., 2014). In addition, SOA contributes more than $70 \%$ of organic aerosol mass concentrations. Although the $\mathrm{SO}_{2}$ concentrations have been decreased by more than $40 \%$ since implementation of the APPCAP, sulfate aerosols still play an important role in the $\mathrm{PM}_{2.5}$ level in Beijing and make up $25.1 \%$ of the $\mathrm{PM}_{2.5}$ mass concentrations, showing high sulfate contributions from the trans-boundary transport and background. The ammonium, nitrate, EC, and unspecified species account for 13.7, 14.1, 5.8, and $6.5 \%$ of the $\mathrm{PM}_{2.5}$ mass concentrations, respectively. Secondary aerosol species dominate the $\mathrm{PM}_{2.5}$ mass concentration in Beijing, with a contribution of $77.9 \%$.

The local emissions contribute more than $20 \%$ of the mass concentrations for the primary aerosol species, but less than $15 \%$ for the secondary aerosol species in Beijing (Table 5). The trans-boundary transport of non-Beijing emissions dominates all the aerosol species levels in Beijing, with contributions exceeding $50 \%$, particularly for SOA and nitrate. In addition, the POA and sulfate background contributions are also high, more than $20 \%$. Although the primary aerosol species of EC and unspecified constituents are not involved in the chemical process and also do not participate in the gas-particle partitioning, the emission interactions still enhance EC and unspecified constituents concentrations, with contributions of around $1.5 \%$, which is caused by the PBLpollution interaction. It is clear that the PBL-pollution interaction plays an important role in the pollutant accumulation in Beijing (Y. Wang et al., 2013; Peng et al., 2016). Mixing of Beijing local emissions with those outside of Beijing increases the aerosol concentrations in the PBL and decreases the incoming solar radiation down to the surface, cooling the temperature of the low-level atmosphere to suppress the development of the PBL and hinder the aerosol dispersion in the vertical direction.

The emission interactions increase the POA and SOA concentrations, with a POA contribution of $5.3 \%$ and a SOA contribution of $5.9 \%$. In the VBS modeling approach, primary organic components are assumed to be semi-volatile and photochemically reactive. Mixing of Beijing local emissions with non-Beijing emissions enhances the organic condensable gases, and considering that the saturation concentrations of the organic condensable gases do not change, more organic condensable gases partition into the particle phase, increasing the POA and SOA concentrations.

The contributions of emission interactions to inorganic aerosols, including sulfate, nitrate, and ammonium, are more complicated, depending on their particle phase and precursor concentrations. In the present study, ISORROPIA (Version 1.7) is used to calculate the thermodynamic equilibrium between the sulfate-nitrate-ammonium-water aerosols and 
Table 5. Aerosol species' contributions (\%) from local emissions, non-Beijing emissions, interactions of both emissions, and background, as well as mass fraction in the total $\mathrm{PM}_{2.5}(\%)$ in Beijing averaged during the period from 5 to 14 July 2015.

\begin{tabular}{lrrrrr}
\hline Emissions & Mass fraction & Beijing & Surroundings & Interactions & Background \\
\hline Species & In total $\mathrm{PM}_{2.5}$ & \multicolumn{1}{c}{$f_{\mathrm{B}}{ }^{\prime}$} & $f_{\mathrm{S}}{ }^{\prime}$ & $f_{\mathrm{BS}}{ }^{\prime}$ & $f_{0}$ \\
\hline EC & 5.8 & 27.0 & 57.9 & 1.5 & 13.6 \\
POA & 9.8 & 20.8 & 49.0 & 5.3 & 24.9 \\
SOA & 25.0 & 14.6 & 64.2 & 5.9 & 15.3 \\
Ammonium & 13.7 & 14.5 & 65.7 & 1.5 & 18.3 \\
Nitrate & 14.1 & 10.1 & 71.7 & 18.1 & 0.1 \\
Sulfate & 25.1 & 6.5 & 52.9 & 3.4 & 37.2 \\
Unspecified & 6.5 & 21.2 & 61.4 & 1.6 & 15.8 \\
\hline
\end{tabular}
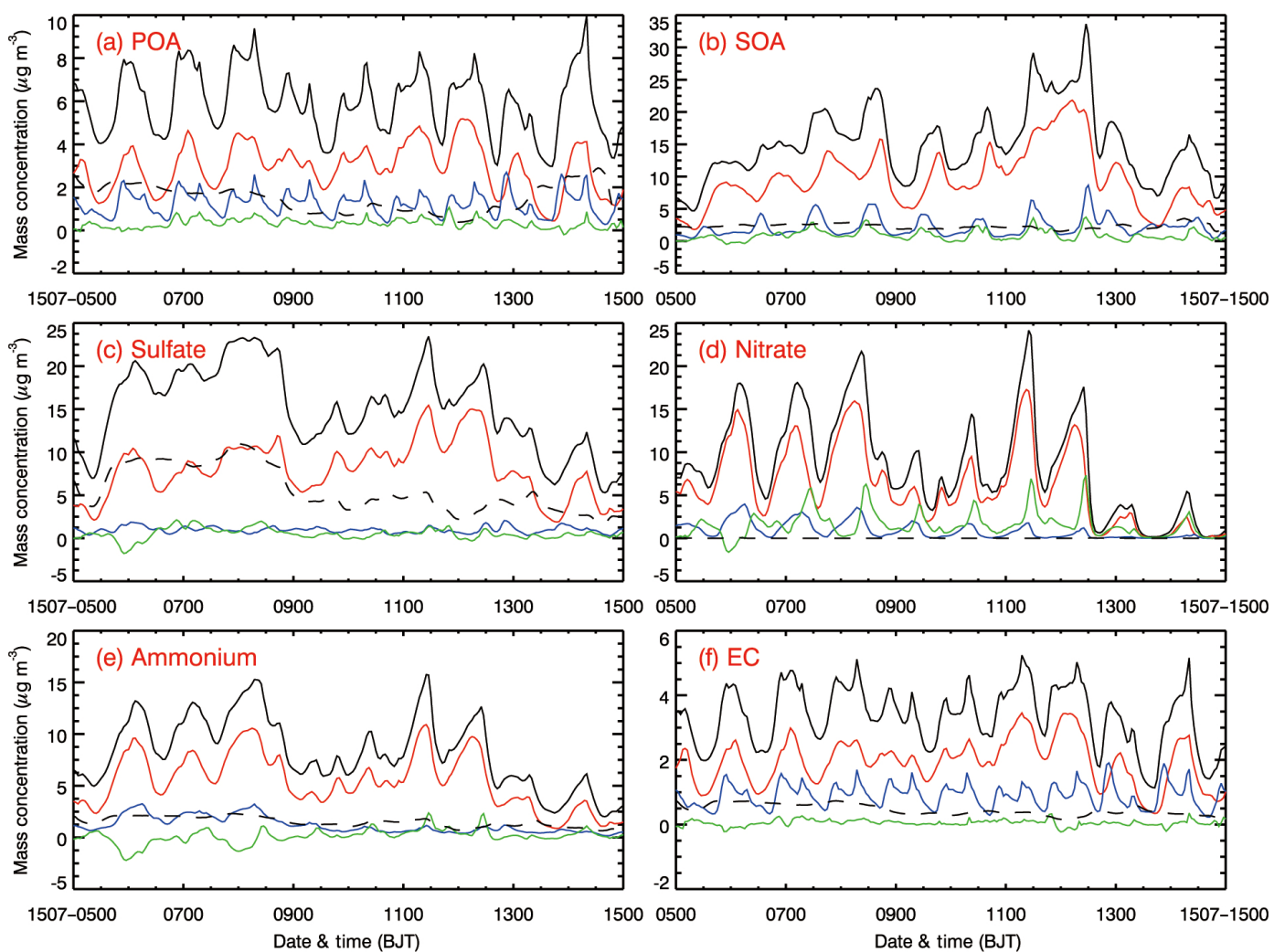

Figure 11. Temporal variations of the average contributions to the near-surface aerosol species concentrations from total emissions (black line, defined as $f_{\mathrm{BS}}$ ), local emissions (blue line, $f_{\mathrm{B}}{ }^{\prime}$, defined as $f_{\mathrm{B}}-f_{0}$ ), non-Beijing emissions (red line, $f_{\mathrm{S}}{ }^{\prime}$, defined as $f_{\mathrm{S}}-f_{0}$ ), the emission interactions (green line, $f_{\mathrm{BS}}{ }^{\prime}$, defined as $f_{\mathrm{BS}}-f_{\mathrm{B}}-f_{\mathrm{S}}+f_{0}$ ), and background (black dashed line, defined as $f_{0}$ ) in Beijing from 5 to 14 July 2015.

their gas phase precursors $\mathrm{H}_{2} \mathrm{SO}_{4}-\mathrm{HNO}_{3}-\mathrm{NH}_{3}$-water vapor. Although mixing of Beijing local emissions with nonBeijing emissions increases inorganic aerosol precursors, the inorganic aerosol contributions from emission interactions are still uncertain due to the thermodynamic equilibrium between inorganic aerosols and their precursors. The nitrate contributions from emission interactions are $18.1 \%$, much more than those for other aerosol constituents. The sulfate contribution from emission interactions is not significant, only $3.4 \%$. The ammonium contributions from emission interactions are $1.5 \%$, similar to those of primary aerosol species.

\section{Summary and conclusions}

In the present study, a persistent air pollution episode with high concentrations of $\mathrm{O}_{3}$ and $\mathrm{PM}_{2.5}$ is simulated using the WRF-CHEM model during the period from 5 to 14 July 
2015 in BTH, to evaluate the contributions of trans-boundary transport to the air quality in Beijing. Although the APPCAP has been implemented since 2013 September, the average $\mathrm{O}_{3}$ concentration in the afternoon has increased by $22.8 \%$ from 2013 to 2015 in Beijing, and Beijing still experienced high $\mathrm{O}_{3}$ and/or $\mathrm{PM}_{2.5}$ concentrations frequently during summertime of 2015.

In general, the predicted temporal variations of $\mathrm{PM}_{2.5}, \mathrm{O}_{3}$, and $\mathrm{NO}_{2}$ concentrations agree well with observations in Beijing and BTH, but the model biases still exist, which are perhaps caused by the uncertainties of simulated meteorological conditions and the emission inventory. The model also successfully reproduces the spatial distributions of $\mathrm{PM}_{2.5}, \mathrm{O}_{3}$, and $\mathrm{NO}_{2}$ concentrations compared with measurements. The model performs reasonably well in modeling the variations of aerosol constituents compared with ACSM measurement at the NCNST site in Beijing, but there are considerable biases in POA and sulfate simulations.

The FSA is used to investigate the contribution of transboundary transport of non-Beijing emissions to the air quality in Beijing. If the Beijing local emissions are not included in model simulations, the $\mathrm{O}_{3}$ and $\mathrm{PM}_{2.5}$ concentrations in Beijing still remain high, showing that the transboundary transport of emissions outside of Beijing plays a more important role in the air quality in Beijing than the Beijing local emissions. On average, the local emissions contribute $22.4 \%$ of $\mathrm{O}_{3}$ in the afternoon and $13.7 \%$ of $\mathrm{PM}_{2.5}$ mass concentrations in Beijing during the episode. The $\mathrm{O}_{3}$ contribution in the afternoon and $\mathrm{PM}_{2.5}$ contribution from the trans-boundary transport of non-Beijing emissions are 36.6 and $61.5 \%$, respectively, far exceeding those from local emissions. The interactions between local and non-Beijing emissions generally decrease the $\mathrm{O}_{3}$ level in the afternoon and increase the $\mathrm{PM}_{2.5}$ level in Beijing during the episode, with contributions of -5.1 and $+4.4 \%$, respectively. In addition, the trans-boundary transport dominates all the aerosol species levels in Beijing, with contributions exceeding $50 \%$ on average, particularly for SOA and nitrate. The emission interactions in general increase all the aerosol species levels due to the PBL-pollution interaction and the enhancement of precursors of secondary aerosols. Hence, the air quality in Beijing during summertime is generally determined by the trans-boundary transport of emissions outside of Beijing.

However, there is still controversy over whether local or non-local emissions play a dominant role in the air quality in Beijing (Guo et al., 2010, 2014; P. Li et al., 2015; R. Zhang et al., 2015). When only considering the local emissions, the summertime $\mathrm{PM}_{2.5}$ level in Beijing is comparable to that in Mexico City. Mexico City has once been one of the most polluted cities in the world, but the air quality has been greatly improved in recent years after taking emission control strategies (Molina et al., 2002, 2007, 2010). Therefore, a comprehensive model comparison of summertime pollution in Mexico City and Beijing would be illuminating for elucidation of the contributions of trans-boundary transport to the air quality in Beijing.

It is worth noting that, although the WRF-CHEM model captures the spatial distributions and temporal variations of pollutants well, the model biases still exist. The discrepancies between the predictions and observations are possibly caused by the uncertainties in the emission inventory and the meteorological field simulations (R. Zhang et al., 2015). BTH has been considered as a polluted air basin (Zhao et al., 2009; Parrish and Stockwell, 2015), which frequently experiences $\mathrm{O}_{3}$ and $\mathrm{PM}_{2.5}$ pollution during summertime. Future studies need to be conducted to improve the WRF-CHEM model simulations, and further to assess the contributions of trans-boundary transport of emissions outside of Beijing to the air quality in Beijing, considering the rapid changes in anthropogenic emissions since implementation of the APPCAP. This study mainly aims at providing a quantification of the effect of trans-boundary transport on the air quality in Beijing. It demonstrates that the effective approach to improving air quality in Beijing is to reduce both local and nonBeijing emissions in BTH. Further sensitivity simulations of different emission reduction measures are needed to design the most efficient emission control strategies.

\section{Data availability}

The real-time $\mathrm{O}_{3}$ and $\mathrm{PM}_{2.5}$ are accessible for the public on the website http://106.37.208.233:20035/ (China MEP, 2013a). One can also access the historic profile of observed ambient pollutants through visiting http://www.aqistudy.cn/ (China MEP, 2013b).

\section{The Supplement related to this article is available online at doi:10.5194/acp-17-2035-2017-supplement.}

Competing interests. The authors declare that they have no conflict of interest.

Acknowledgements. This work was supported by the National Natural Science Foundation of China (no. 41275153) and the "Strategic Priority Research Program" of the Chinese Academy of Science, grant no. XDB05060500. Guohui Li is also supported by the "Hundred Talents Program" of the Chinese Academy of Sciences. Naifang Bei is supported by the National Natural Science Foundation of China (No. 41275101).

Edited by: D. Parrish

Reviewed by: three anonymous referees 


\section{References}

An, X., Zhu, T., Wang, Z., Li, C., and Wang, Y.: A modeling analysis of a heavy air pollution episode occurred in Beijing, Atmos. Chem. Phys., 7, 3103-3114, doi:10.5194/acp-7-3103-2007, 2007.

Bei, N., Lei, W., Zavala, M., and Molina, L. T.: Ozone predictabilities due to meteorological uncertainties in the Mexico City basin using ensemble forecasts, Atmos. Chem. Phys., 10, 6295-6309, doi:10.5194/acp-10-6295-2010, 2010.

Bei, N., Li, G., and Molina, L. T.: Uncertainties in SOA simulations due to meteorological uncertainties in Mexico City during MILAGRO-2006 field campaign, Atmos. Chem. Phys., 12, 11295-11308, doi:10.5194/acp-12-11295-2012, 2012.

Bei, N. F., Li, G. H., Zavala, M., Barrera, H., Torres, R., Grutter, M., Gutierrez, W., Garcia, M., Ruiz-Suarez, L. G., Ortinez, A., Guitierrez, Y., Alvarado, C., Flores, I., and Molina, L. T.: Meteorological overview and plume transport patterns during Cal-Mex 2010, Atmos. Environ., 70, 477-489, doi:10.1016/j.atmosenv.2012.01.065, 2013.

Binkowski, F. S. and Roselle, S. J.: Models-3 Community Multiscale Air Quality (CMAQ) model aerosol component: 1. Model description, J. Geophys. Res.-Atmos., 108, 4183, doi:10.1029/2001JD001409, 2003.

Carnevale, C., Pisoni, E., and Volta, M.: A non-linear analysis to detect the origin of $\mathrm{PM}_{10}$ concentrations in Northern Italy, Sci. Total Environ., 409, 182-191, doi:10.1016/j.scitotenv.2010.09.038, 2010.

Chen, F. and Dudhia, J.: Coupling an advanced land surfacehydrology model with the Penn State-NCAR MM5 modeling system. Part I: Model implementation and sensitivity, Mon. Weather Rev., 129, 569-585, doi:10.1175/15200493(2001)129<0569:caalsh>2.0.co;2, 2001.

Chen, W., Yan, L., and Zhao, H. M.: Seasonal Variations of Atmospheric Pollution and Air Quality in Beijing, Atmosphere, 6, 1753-1770, doi:10.3390/atmos6111753, 2015.

Chou, M. D. and Suarez, M. J.: A solar radiation parameterization for atmospheric studies, NASA TM-104606, Nasa Tech.memo, 15, 1999.

Chou, M. D., Suarez, M. J., Liang, X. Z., Yan, M. H., and Cote, C.: A Thermal Infrared Radiation Parameterization for Atmospheric Studies, NASA TM-2001-104606, Max. J., 19, 2001.

Fan, J. W. and Zhang, R. Y.: Atmospheric Oxidation Mechanism of Isoprene, Environ. Chem., 1, 140-149, doi:10.1071/en04045, 2004.

Fan, J. W., Zhang, R. Y., Collins, D., and Li, G. H.: Contribution of secondary condensable organics to new particle formation: A case study in Houston, Texas, Geophys. Res. Lett., 33, L15802, doi:10.1029/2006g1026295, 2006.

Gabusi, V., Pisoni, E., and Volta, M.: Factor separation in air quality simulations, Ecol. Model., 218, 383-392, doi:10.1016/j.ecolmodel.2008.07.030, 2008.

Gomez, M. E., Lin, Y., Guo, S., and Zhang, R. Y.: Heterogeneous Chemistry of Glyoxal on Acidic Solutions. An Oligomerization Pathway for Secondary Organic Aerosol Formation, J. Phys. Chem. A, 119, 4457-4463, doi:10.1021/jp509916r, 2015.

Guenther, A., Karl, T., Harley, P., Wiedinmyer, C., Palmer, P. I., and Geron, C.: Estimates of global terrestrial isoprene emissions using MEGAN (Model of Emissions of Gases and Aerosols from
Nature), Atmos. Chem. Phys., 6, 3181-3210, doi:10.5194/acp-63181-2006, 2006.

Guo, S., Hu, M., Wang, Z. B., Slanina, J., and Zhao, Y. L.: Sizeresolved aerosol water-soluble ionic compositions in the summer of Beijing: implication of regional secondary formation, Atmos. Chem. Phys., 10, 947-959, doi:10.5194/acp-10-947-2010, 2010.

Guo, S., Hu, M., Zamora, M. L., Peng, J. F., Shang, D. J., Zheng, J., Du, Z. F., Wu, Z., Shao, M., Zeng, L. M., Molina, M. J., and Zhang, R. Y.: Elucidating severe urban haze formation in China, P. Natl. Acad. Sci. USA, 111, 17373-17378, doi:10.1073/pnas.1419604111, 2014.

Hong, S.-Y. and Lim, J.-O. J.: The WRF Single-Moment 6-Class Microphysics Scheme (WSM6), Asia-Pacific Journal of Atmospheric Sciences, 42, 129-151, 2006.

Horowitz, L. W., Walters, S., Mauzerall, D. L., Emmons, L. K., Rasch, P. J., Granier, C., Tie, X. X., Lamarque, J. F., Schultz, M. G., Tyndall, G. S., Orlando, J. J., and Brasseur, G. P.: A global simulation of tropospheric ozone and related tracers: Description and evaluation of MOZART, version 2, J. Geophys. Res.-Atmos., 108, 4784, doi:10.1029/2002jd002853, 2003.

Janjić, Z. I.: Nonsingular Implementation of the Mellor-Yamada Level 2.5 Scheme in the NCEP Meso Model, Ncep Office Note, 436, 2002.

Jiang, C., Wang, H., Zhao, T., Li, T., and Che, H.: Modeling study of $\mathrm{PM}_{2.5}$ pollutant transport across cities in China's Jing-JinJi region during a severe haze episode in December 2013, Atmos. Chem. Phys., 15, 5803-5814, doi:10.5194/acp-15-58032015, 2015.

Jiang, F., Wang, T. J., Wang, T. T., Xie, M., and Zhao, H.: Numerical modeling of a continuous photochemical pollution episode in Hong Kong using WRF-Chem, Atmos. Environ., 42, 8717-8727, doi:10.1016/j.atmosenv.2008.08.034, 2008.

Kulmala, M., Laaksonen, A., and Pirjola, L.: Parameterizations for sulfuric acid/water nucleation rates, J. Geophys. Res.-Atmos., 103, 8301-8307, 1998.

Lang, J. L., Cheng, S. Y., Li, J. B., Chen, D. S., Zhou, Y., Wei, X., Han, L. H., and Wang, H. Y.: A Monitoring and Modeling Study to Investigate Regional Transport and Characteristics of $\mathrm{PM}_{2.5}$ Pollution, Aerosol and Air Quality Research, 13, 943956, doi:10.4209/aaqr.2012.09.0242, 2013.

Lei, W., de Foy, B., Zavala, M., Volkamer, R., and Molina, L. T.: Characterizing ozone production in the Mexico City Metropolitan Area: a case study using a chemical transport model, Atmos. Chem. Phys., 7, 1347-1366, doi:10.5194/acp-7-1347-2007, 2007.

Lei, W., Zavala, M., de Foy, B., Volkamer, R., and Molina, L. T.: Characterizing ozone production and response under different meteorological conditions in Mexico City, Atmos. Chem. Phys., 8, 7571-7581, doi:10.5194/acp-8-7571-2008, 2008.

Li, G., Zhang, R., Fan, J., and Tie, X.: Impacts of black carbon aerosol on photolysis and ozone, J. Geophys. Res., 110, D23206, doi:10.1029/2005jd005898, 2005.

Li, G., Zhang, R., Fan, J., and Tie, X.: Impacts of biogenic emissions on photochemical ozone production in Houston, Texas, J. Geophys. Res., 112, D10309, doi:10.1029/2006jd007924, 2007.

Li, G., Lei, W., Zavala, M., Volkamer, R., Dusanter, S., Stevens, P., and Molina, L. T.: Impacts of HONO sources on the photochemistry in Mexico City during the MCMA-2006/MILAGO Cam- 
paign, Atmos. Chem. Phys., 10, 6551-6567, doi:10.5194/acp-106551-2010, 2010.

Li, G., Bei, N., Tie, X., and Molina, L. T.: Aerosol effects on the photochemistry in Mexico City during MCMA2006/MILAGRO campaign, Atmos. Chem. Phys., 11, 51695182, doi:10.5194/acp-11-5169-2011, 2011a.

Li, G., Zavala, M., Lei, W., Tsimpidi, A. P., Karydis, V. A., Pandis, S. N., Canagaratna, M. R., and Molina, L. T.: Simulations of organic aerosol concentrations in Mexico City using the WRFCHEM model during the MCMA-2006/MILAGRO campaign, Atmos. Chem. Phys., 11, 3789-3809, doi:10.5194/acp-11-37892011, 2011b.

Li, G., Lei, W., Bei, N., and Molina, L. T.: Contribution of garbage burning to chloride and $\mathrm{PM}_{2.5}$ in Mexico City, Atmos. Chem. Phys., 12, 8751-8761, doi:10.5194/acp-12-8751-2012, 2012.

Li, G. H., Bei, N. F., Zavala, M., and Molina, L. T.: Ozone formation along the California Mexican border region during Cal-Mex 2010 field campaign, Atmos. Environ., 88, 370-389, doi:10.1016/j.atmosenv.2013.11.067, 2014.

Li, G., Bei, N., Cao, J., Huang, R., Wu, J., Feng, T., Wang, Y., Liu, S., Zhang, Q., Tie, X., and Molina, L.: A Possible Pathway for Rapid Growth of Sulfate during Haze Days in China, Atmos. Chem. Phys. Discuss., doi:10.5194/acp-2016-994, in review, 2016.

Li, P., Yan, R., Yu, S., Wang, S., Liu, W., and Bao, H.: Reinstate regional transport of $\mathrm{PM}_{2.5}$ as a major cause of severe haze in Beijing, P. Natl. Acad. Sci. USA, 112, 2739-2740, 2015.

Li, R. K., Li, Z. P., Gao, W. J., Ding, W. J., Xu, Q., and Song, X. F.: Diurnal, seasonal, and spatial variation of $\mathrm{PM}_{2.5}$ in Beijing, Chinese Science Bulletin, 60, 387-395, doi:10.1007/s11434-0140607-9, 2015.

Liu, Z. R., Hu, B., Wang, L. L., Wu, F. K., Gao, W. K., and Wang, Y. S.: Seasonal and diurnal variation in particulate matter $\left(\mathrm{PM}_{10}\right.$ and $\left.\mathrm{PM}_{2.5}\right)$ at an urban site of Beijing: analyses from a 9-year study, Environ. Sci. Pollut. Res., 22, 627-642, doi:10.1007/s11356-014-3347-0, 2015.

Long, X., Tie, X., Cao, J., Huang, R., Feng, T., Li, N., Zhao, S., Tian, J., Li, G., and Zhang, Q.: Impact of crop field burning and mountains on heavy haze in the North China Plain: a case study, Atmos. Chem. Phys., 16, 9675-9691, doi:10.5194/acp-16-96752016, 2016.

Meng, W., Gao, Q., Zhang, Z., Liao, Q., Lei, t., Li, J., Kang, N., and Ren, Z.: The Numerical Study of Atmospheric Pollution in Beijing and Its Surrounding Regions, Res. Environ. Sci., 19, 1118, 2006.

Ministry of Environmental Protection, China (China MEP): Air Quality Observation Real-time Release Platform of MEP Data Center, available at: http://106.37.208.233:20035/, 2013a.

Ministry of Environmental Protection, China (China MEP): Online Monitoring and Analysis Platform of China Air Quality, available at: http://www.aqistudy.cn/, 2013b.

Mlawer, E. J., Taubman, S. J., Brown, P. D., Iacono, M. J., and Clough, S. A.: Radiative transfer for inhomogeneous atmospheres: RRTM, a validated correlated-k model for the longwave, J. Geophys. Res.-Atmos., 102, 16663-16682, doi:10.1029/97jd00237, 1997.

Molina, L. T. and Molina, M. J.: Air Quality in the Mexico Megacity: An Integrated Assessment, Kluwer Academic Publishers: Dordrecht, The Netherlands, 384 pp., 2002.
Molina, L. T., Kolb, C. E., de Foy, B., Lamb, B. K., Brune, W. H., Jimenez, J. L., Ramos-Villegas, R., Sarmiento, J., ParamoFigueroa, V. H., Cardenas, B., Gutierrez-Avedoy, V., and Molina, M. J.: Air quality in North America's most populous city overview of the MCMA-2003 campaign, Atmos. Chem. Phys., 7, 2447-2473, doi:10.5194/acp-7-2447-2007, 2007.

Molina, L. T., Madronich, S., Gaffney, J. S., Apel, E., de Foy, B., Fast, J., Ferrare, R., Herndon, S., Jimenez, J. L., Lamb, B., Osornio-Vargas, A. R., Russell, P., Schauer, J. J., Stevens, P. S., Volkamer, R., and Zavala, M.: An overview of the MILAGRO 2006 Campaign: Mexico City emissions and their transport and transformation, Atmos. Chem. Phys., 10, 8697-8760, doi:10.5194/acp-10-8697-2010, 2010.

Nenes, A., Pilinis, C., and Pandis, S. N.: ISORROPIA: A New thermodynamic equilibrium model for multiphase multicomponent inorganic aerosols, Aquat. Geochem., 4, 123-152, 1998.

Parrish, D. and Zhu, T.: Clean air for Megacities, Science, 326, 674 675, 2009.

Parrish, D. D. and Stockwell, W. R.: Urbanization and Air Pollution: Then and Now, 96, 2015.

Peng, J. F., Hu, M., Guo, S., Du, Z. F., Zheng, J., Shang, D. J., Zamora, M. L., Zeng, L. M., Shao, M., Wu, Y. S., Zheng, J., Wang, Y., Glen, C. R., Collins, D. R., Molina, M. J., and Zhang, R. Y.: Markedly enhanced absorption and direct radiative forcing of black carbon under polluted urban environments, P. Natl. Acad. Sci. USA, 113, 4266-4271, doi:10.1073/pnas.1602310113, 2016.

Sillman, S., Logan, J. A., and Wofsy, S. C.: The sensitivity of ozone to nitrogen oxides and hydrocarbons in regional ozone episode, J. Geophys. Res.-Atmos., 95, 1837-1851, doi:10.1029/JD095iD02p01837, 1990.

Stein, U. and Alpert, P.: Factor separation in numerical simulations, J. Atmos. Sci., 50, 2107-2115, doi:10.1175/15200469(1993)050<2107:fsins>2.0.co; 2, 1993.

Streets, D. G., Fu, J. S., Jang, C. J., Hao, J. M., He, K. B., Tang, X. Y., Zhang, Y. H., Wang, Z. F., Li, Z. P., Zhang, Q., Wang, L. T., Wang, B. Y., and Yu, C.: Air quality during the 2008 Beijing Olympic Games, Atmos. Environ., 41, 480-492, doi:10.1016/j.atmosenv.2006.08.046, 2007.

Suarex, M. J. and Chou, M. D.: Technical report series on global modeling and data assimilation. Volume 3: An efficient thermal infrared radiation parameterization for use in general circulation models, NASA Tech. Memo-104606, 3, 1603-1609, 1994.

Suh, I., Zhang, R. Y., Molina, L. T., and Molina, M. J.: Oxidation mechanism of aromatic peroxy and bicyclic radicals from OH-toluene reactions, J. Am. Chem. Soc., 125, 12655-12665, doi:10.1021/ja0350280, 2003.

Sun, Y. L., Jiang, Q., Wang, Z. F., Fu, P. Q., Li, J., Yang, T., and Yin, Y.: Investigation of the sources and evolution processes of severe haze pollution in Beijing in January 2013, J. Geophys. Res.Atmos., 119, 4380-4398, doi:10.1002/2014jd021641, 2014.

Tang, G., Li, X., Wang, Y., Xin, J., and Ren, X.: Surface ozone trend details and interpretations in Beijing, 2001-2006, Atmos. Chem. Phys., 9, 8813-8823, doi:10.5194/acp-9-8813-2009, 2009.

Tang, G., Wang, Y., Li, X., Ji, D., Hsu, S., and Gao, X.: Spatialtemporal variations in surface ozone in Northern China as observed during 2009-2010 and possible implications for future air quality control strategies, Atmos. Chem. Phys., 12, 2757-2776, doi:10.5194/acp-12-2757-2012, 2012. 
Tang, G., Zhang, J., Zhu, X., Song, T., Münkel, C., Hu, B., Schäfer, K., Liu, Z., Zhang, J., Wang, L., Xin, J., Suppan, P., and Wang, Y.: Mixing layer height and its implications for air pollution over Beijing, China, Atmos. Chem. Phys., 16, 2459-2475, doi:10.5194/acp-16-2459-2016, 2016.

Tao, M. H., Chen, L. F., Xiong, X. Z., Zhang, M. G., Ma, P. F., Tao, J. H., and Wang, Z. F.: Formation process of the widespread extreme haze pollution over northern China in January 2013: Implications for regional air quality and climate, Atmos. Environ., 98, 417-425, doi:10.1016/j.atmosenv.2014.09.026, 2014.

Volkamer, R., San Martini, F., Molina, L. T., Salcedo, D., Jimenez, J. L., and Molina, M. J.: A Missing Sink for Gas-Phase Glyoxal in Mexico City: Formation of Secondary Organic Aerosol, Geophys. Res. Lett., 34, L19807, doi:10.1029/2007GL030752, 2007.

Wang, H., Xue, M., Zhang, X. Y., Liu, H. L., Zhou, C. H., Tan, S. C., Che, H. Z., Chen, B., and Li, T.: Mesoscale modeling study of the interactions between aerosols and PBL meteorology during a haze episode in Jing-Jin-Ji (China) and its nearby surrounding region - Part 1: Aerosol distributions and meteorological features, Atmos. Chem. Phys., 15, 3257-3275, doi:10.5194/acp-15-32572015, 2015.

Wang, L. L., Liu, Z. R., Sun, Y., Ji, D. S., and Wang, Y. S.: Longrange transport and regional sources of $\mathrm{PM}_{2.5}$ in Beijing based on long-term observations from 2005 to 2010, Atmos. Res., 157, 37-48, doi:10.1016/j.atmosres.2014.12.003, 2015.

Wang, L. T., Wei, Z., Yang, J., Zhang, Y., Zhang, F. F., Su, J., Meng, C. C., and Zhang, Q.: The 2013 severe haze over southern Hebei, China: model evaluation, source apportionment, and policy implications, Atmos. Chem. Phys., 14, 3151-3173, doi:10.5194/acp-14-3151-2014, 2014.

Wang, X. S., Li, J. L., Zhang, Y. H., Xie, S. D., and Tang, X. Y.: Ozone source attribution during a severe photochemical smog episode in Beijing, China, Science China Chemistry, 52, 12701280, doi:10.1007/s11426-009-0137-5, 2009.

Wang, Y., Konopka, P., Liu, Y., Chen, H., Müller, R., Plöger, F., Riese, M., Cai, Z., and Lü, D.: Tropospheric ozone trend over Beijing from 2002-2010: ozonesonde measurements and modeling analysis, Atmos. Chem. Phys., 12, 8389-8399, doi:10.5194/acp-12-8389-2012, 2012.

Wang, Y., Khalizov, A., Levy, M., and Zhang, R. Y.: New Directions: Light absorbing aerosols and their atmospheric impacts, Atmos. Environ., 81, 713-715, doi:10.1016/j.atmosenv.2013.09.034, 2013.

Wang, Y. H., Hu, B., Tang, G. Q., Ji, D. S., Zhang, H. X., Bai, J. H., Wang, X. K., and Wang, Y. S.: Characteristics of ozone and its precursors in Northern China: A comparative study of three sites, Atmos. Res., 132, 450-459, doi:10.1016/j.atmosres.2013.04.005, 2013.

Wang, Z., Li, Y., Chen, T., Zhang, D., Sun, F., Wang, X., Huan, N., and Pan, L.: Analysis on diurnal variation characteristics of ozone and correlations with its precursors in urban atmosphere of Beijing, China Environmental Science, 34, 3001-3008, 2014.

Wang, Z., Zhang, D., Li, Y., Dong, X., Sun, R., and Sun, N.: Different Air Pollution Situations of $\mathrm{O}_{3}$ and $\mathrm{PM}_{2.5}$ During Summer in Beijing, Environ. Sci., 37, 807-815, 2016.

Wang, Z. F., Li-Na, L. I., Qi-Zhong, W. U., Gao, C., Xin, L. I., Student, G., and PhD: Simulation of the Impacts of Regional Transport on Summer Ozone Levels Over Beijing, Chinese Journal of Nature, 30, 194-198, 2008.
Weinroth, E., Luria, M., Emery, C., Ben-Nun, A., Bornstein, R., Kaplan, J., Peleg, M., and Mahrer, Y.: Simulations of Mideast transboundary ozone transport: A source apportionment case study, Atmos. Environ., 42, 3700-3716, doi:10.1016/j.atmosenv.2008.01.002, 2008.

Wesely, M. L.: Parameterization of surface resistances to gaseous dry deposition in regional-scale numerical models, Atmos. Environ., 23, 1293-1304, doi:10.1016/0004-6981(89)90153-4, 1989.

Xie, Y. Y., Wang, Y. X., Zhang, K., Dong, W. H., Lv, B. L., and Bai, Y. Q.: Daily Estimation of Ground-Level $\mathrm{PM}_{2.5}$ Concentrations over Beijing Using $3 \mathrm{~km}$ Resolution MODIS AOD, Environ. Sci. Technol., 49, 12280-12288, doi:10.1021/acs.est.5b01413, 2015.

Yang, T., Wang, Z. F., Zhang, B., Wang, X. Q., Wang, W., Gbauidi, A., and Gong, Y. B.: Evaluation of the effect of air pollution control during the Beijing 2008 Olympic Games using Lidar data, Chinese Science Bulletin, 55, 1311-1316, doi:10.1007/s11434010-0081-y, 2010.

Zhang, J. P., Zhu, T., Zhang, Q. H., Li, C. C., Shu, H. L., Ying, Y., Dai, Z. P., Wang, X., Liu, X. Y., Liang, A. M., Shen, H. X., and Yi, B. Q.: The impact of circulation patterns on regional transport pathways and air quality over Beijing and its surroundings, Atmos. Chem. Phys., 12, 5031-5053, doi:10.5194/acp-12-50312012, 2012.

Zhang, L., Liao, H., and Li, J. P.: Impacts of Asian summer monsoon on seasonal and interannual variations of aerosols over eastern China, J. Geophys. Res.-Atmos., 115, D00K05, doi:10.1029/2009jd012299, 2010.

Zhang, Q., Streets, D. G., Carmichael, G. R., He, K. B., Huo, H., Kannari, A., Klimont, Z., Park, I. S., Reddy, S., Fu, J. S., Chen, D., Duan, L., Lei, Y., Wang, L. T., and Yao, Z. L.: Asian emissions in 2006 for the NASA INTEX-B mission, Atmos. Chem. Phys., 9, 5131-5153, doi:10.5194/acp-9-5131-2009, 2009.

Zhang, Q., Yuan, B., Shao, M., Wang, X., Lu, S., Lu, K., Wang, M., Chen, L., Chang, C.-C., and Liu, S. C.: Variations of ground-level $\mathrm{O} 3$ and its precursors in Beijing in summertime between 2005 and 2011, Atmos. Chem. Phys., 14, 6089-6101, doi:10.5194/acp-14-6089-2014, 2014.

Zhang, R., Wang, L., Khalizova, A. F., Zhao, J., Zheng, J., McGrawb, R. L., and Molina, L. T.: Formation of nanoparticles of blue haze enhanced by anthropogenic pollution, P. Natl. Acad. Sci. USA, 106, 17650-17654, 2009.

Zhang, R., Khalizova, A. F., Wang, L., Hu, M., and Xu, W.: Nucleation and growth of nanoparticles in the atmosphere, Chem. Rev., 112, 1957-2011, 2012.

Zhang, R., Jing, J., Tao, J., Hsu, S.-C., Wang, G., Cao, J., Lee, C. S. L., Zhu, L., Chen, Z., Zhao, Y., and Shen, Z.: Chemical characterization and source apportionment of $\mathrm{PM}_{2.5}$ in Beijing: seasonal perspective, Atmos. Chem. Phys., 13, 7053-7074, doi:10.5194/acp-13-7053-2013, 2013.

Zhang, R., Guo, S., Levy, Z. M., and Hu, M.: Reply to Li et al.: Insufficient evidence for the contribution of regional transport to severe haze formation in Beijing, P. Natl. Acad. Sci. USA, 112, E2741, doi:10.1073/pnas.1503855112, 2015.

Zhang, R. Y., Wang, G. H., Guo, S., Zarnora, M. L., Ying, Q., Lin, Y., Wang, W. G., Hu, M., and Wang, Y.: Formation of Urban Fine Particulate Matter, Chem. Rev., 115, 3803-3855, doi:10.1021/acs.chemrev.5b00067, 2015.

Zhao, C., Wang, Y., and Zeng, T.: East China plains: a "basin" of ozone pollution, Environ. Sci. Technol., 43, 1911-1915, 2009. 
Zhao, J., Levitt, N. P., Zhang, R. Y., and Chen, J. M.: Heterogeneous reactions of methylglyoxal in acidic media: implications for secondary organic aerosol formation, Environ. Sci. Technol., 40, 7682-7687, 2006.
Zheng, S., Pozzer, A., Cao, C. X., and Lelieveld, J.: Long-term (2001-2012) concentrations of fine particulate matter $\left(\mathrm{PM}_{2.5}\right)$ and the impact on human health in Beijing, China, Atmos. Chem. Phys., 15, 5715-5725, doi:10.5194/acp-15-5715-2015, 2015. 